\title{
Aging and life history traits of the longnose spiny dogfish in the Mediterranean Sea: New insights into conservation and management needs
}

\author{
Vasiliki Kousteni, Persefoni Megalofonou* \\ Faculty of Biology, Department of Zoology-Marine Biology, University of Athens, Panepistimiopolis, Ilisia, 15784 Athens, Greece
}

\section{A R T I C L E I N F O}

\section{Article history:}

Received 26 May 2014

Received in revised form 9 March 2015

Accepted 16 March 2015

Handling editor: B. Morales-Nin

\section{Keywords:}

Squalus blainville

Fin spine morphometry

Age

Growth

Condition factor

Age at maturity

\begin{abstract}
A B S T R A C T
Aging chondrichthyans has been characterized as a slow and difficult process, but at the same time it is considered of fundamental importance for the holistic management and conservation of their populations. This study aims to assess the age and growth of the longnose spurdog S. blainville, to correlate the results to the species' biological features and to compare them with those reported in previous studies that used different aging methods. By counting the growth bands on the enamel surface of the dorsal fin spines, age was estimated in 569 out of 810 individuals that were taken as by-catch from commercial fisheries in the Mediterranean Sea during an 8-year period. Spine morphometrics revealed sexual dimorphism as far as spine length, spine base width and spine weight are concerned. The between-sex differences were also reflected in the length-weight relationships, in the gonadosomatic (GSI) and hepatosomatic (HSI) indices, and in the condition factor (K). All three somatic indices differed significantly among maturity stages, seasons or age classes. The reproducibility of the age readings was considered high based on the estimated CV and APE precision indices. Age bias plots also indicated no significant intra- and small inter-reader variation. The estimated VBGF parameters were: $L_{\infty}=1097.3 \mathrm{~mm}, k=0.03$ $\mathrm{yr}^{-1}$ and $t_{0}=-5.58 \mathrm{yrs}$ for females, and $L_{\infty}=665.5 \mathrm{~mm}, k=0.08 \mathrm{yr}^{-1}$ and $t_{0}=-3.35 \mathrm{yrs}$ for males. Likelihood ratio tests showed that all growth parameters were statistically significantly different between sexes $\left(\chi^{2}=38.26, d f=3, P<0.001\right)$. Females reached higher longevity (28 yrs) than males $(22 \mathrm{yrs})$ and attained maturity at higher age and larger size $\left(T_{50}=17 \mathrm{yrs}\right.$ and $\left.L_{50}=568.1 \mathrm{~mm}\right)$ than males did $\left(T_{50}=11.3\right.$ yrs and $\left.L_{50}=460.6 \mathrm{~mm}\right)$. S. blainville seems to be a long-lived shark of slow growth and late maturity, a combination of traits indicating a species of great vulnerability to fishing pressure that can only sustain a low harvest rate.
\end{abstract}

(C) 2015 Published by Elsevier B.V.

\section{Introduction}

Assessing growth parameters is important not only for the prediction of growth rate evolution, identification of cohorts and evaluation of population dynamics, but also for the definition of strategies for sustainable fisheries (Rochet and Trenkel, 2003). Considering the current concern over the shark catches in the Mediterranean Sea (Dulvy et al., 2014) in conjunction with their inherent life history traits (Musick, 1999; Kyne and Simpfendorfer, 2007) that make them vulnerable to overexploitation (Stevens et al., 2000), it is of high importance to implement integrated management measures for their population stocks that include, among

\footnotetext{
* Corresponding author. Tel.: +30 2107274620; fax: +30 2107274620 .

E-mail address: pmegalo@biol.uoa.gr (P. Megalofonou).
}

others, species-specific information on their demographic characteristics.

Age and growth studies in chondrichthyans are based on vertebrae, dorsal fin spines, caudal thorns and neural arches, since they lack the hard parts that teleosts have, such as otoliths, scales and bones (Cailliet and Goldman, 2004). Spines, which are present in the three extant orders of Squaliformes, Heterodontiformes and Chimaeriformes (Maisey, 1979), are considered useful for aging species baring large enamel caps and most notably squalid sharks (Cailliet and Goldman, 2004), in contrast to other species having either a thin enamel layer on the anterior external surface of the spine or none at all (Cotton et al., 2014). In some cases, the spines appear to offer the only means of age estimation, for example in sharks whose vertebral centra, despite their wide use in aging chondrichthyans (Cailliet, 1990), did not prove useful for this purpose even after applying band enhancing techniques (Clarke et al., 2002a; Irvine et al., 2006a; Coelho and Erzini, 2007, 2008; 


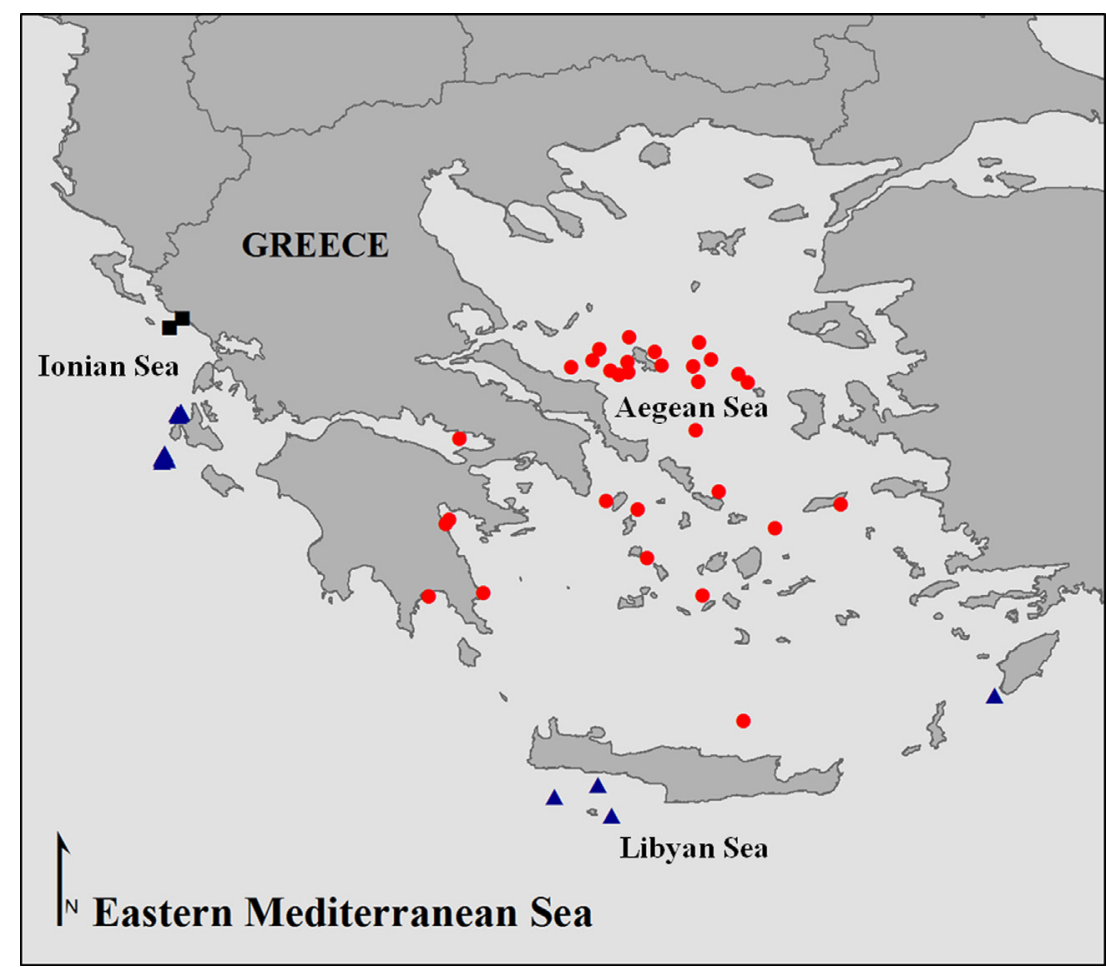

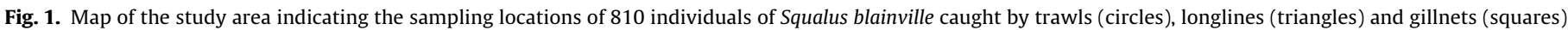
in the eastern Mediterranean Sea.

Cotton et al., 2011). The most common squalid shark whose spines were examined externally in aging studies is the piked dogfish Squalus acanthias (e.g. Kaganovskaia, 1933; Holden and Meadows, 1962; Jensen, 1965; Ketchen, 1975; Soldat, 1982; Saunders and McFarlane, 1993; Tribuzio et al., 2010; Orlov et al., 2011; Bubley et al., 2012).

The longnose spurdog Squalus blainville (Risso, 1826) is a demersal shark inhabiting the continental shelves and upper slopes of the Atlantic, Pacific, and Indian Oceans, including the Mediterranean and Black Seas (Compagno, 1984). Although its occurrence in the Mediterranean Sea has been recorded since the early 80s (Ondrias, 1971), few studies have been focused on its life history traits. Specifically, till present it has become known that S. blainville is an ovoviviparous shark that is involved in the production of few embryos and in a continuous reproductive activity during the year (Cannizaro et al., 1995; Sion et al., 2003; Kousteni and Megalofonou, 2011). Its feeding is based mainly on crustaceans, teleosts, molluscs, polychaetes, echinoderms and sipunculids (Capapé, 1975; Kabasakal, 2002; Martinho et al., 2012). Little knowledge exists about the species' age and growth delivered by counting the growth bands in sections of either vertebrae (Cannizaro et al., 1995) or spines (Marouani et al., 2012). Although the presence of bands on the external enamel surface of the dorsal fin spines has long been reported in the co-generic species S. acanthias (Holden and Meadows, 1962), they have not been examined in S. blainville till present.

In the Mediterranean Sea where S. blainville is a commercial bycatch species, official records of its landings are not available, and thus the IUCN categorize it as Data Deficient (DD) (IUCN, 2014). The main objectives of this study are: (a) to estimate the age of $S$. blainville using for the first time the external surface of the dorsal fin spines, (b) to analyze spine morphometrics, (c) to evaluate the precision of the aging method and compare the results with those found in previous studies using different methods, and (d) to evaluate the basic life history traits of the species, such as growth parameters, longevity, age and size at first maturity. All the above information is considered of high importance for management decision making that could contribute to the species' conservation in the Mediterranean Sea.

\section{Materials and methods}

\subsection{Sampling}

Between December 2004 and March 2012 a total of 810 longnose spurdogs were incidentally caught by the commercial fishing vessels using three types of gears (trawls, longlines and gillnets) in the eastern Mediterranean Sea (Fig. 1). All samples from the Aegean Sea $(N=584)$ were collected on board during seasonal fishing operations, while those from the Ionian $(N=174)$ and Libyan Seas $(N=52)$ were obtained at landings. All specimens were initially preserved in ice and later frozen until dissection. Sex was determined by direct examination of the presence or absence of the claspers and overall sex ratio (females:males) was calculated. Total length $(\mathrm{TL})$ was measured to the nearest millimeter $(\mathrm{mm})$, while total weight (TW) and eviscerated weight (EW) were measured to the nearest gram $(\mathrm{g})$. The number and sex of embryos occupying the oviducts of gravid females were also recorded along with their TL and TW without the yolk sac weight.

\subsection{Spine preparation and morphometry}

Both first and second dorsal fin spines were removed, when present, by cutting at the base of the dorsal fins toward the vertebral column. Care was taken to include the delicate base portion. Spines were dipped for few minutes in boiled water in order to facilitate the removal of the excess tissue. Afterwards they were washed, air-dried and finally stored in labeled paper envelopes.

Spine morphometrics (Fig. 2A, Table 1) were recorded only in the second dorsal fin spine, which was mainly considered in the 
A
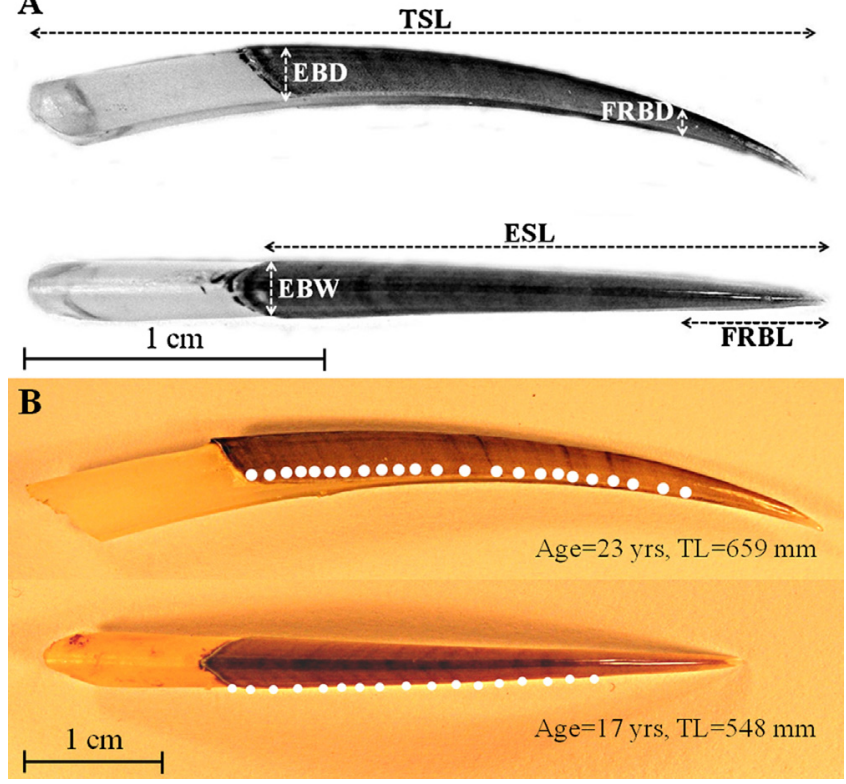

Fig. 2. Schematic representation of the second dorsal fin spine morphometrics recorded for Squalus blainville in the present study (A); Second dorsal fin spines with well pronounced annual growth increments (white circles) of two female $S$. blainville of different size (B).

aging procedure. Given that the point where the first growth band is formed is a critical component for obtaining absolute ages (Beamish and McFarlane, 1983; Campana, 2001), the spine diameter at that point (FRBD) and its distance to the spine tip (FRBL) were recorded when possible. Spine morphometrics were obtained in juveniles and adults with a caliper of $0.01 \mathrm{~mm}$ accuracy, while in embryos using a stereoscope (Carl Zeiss, Axiolab) and the Image analysis software v.6 (Image-Pro ${ }^{\circledR}$ Plus) because of their small size. Spine weight (SW) was recorded with an electronic precision balance of $0.0001 \mathrm{~g}$ readability. Each measurement was eventually taken for a different number of spines, which was subject to their condition (e.g. level of wear).

\subsection{Age estimation, reading precision and aging bias}

Age estimation was based on counting the bands of pigment on the external surface of the dorsal fin spines. These dark bands are actually associated with ridges of enamel, which were proved to be annual in the co-generic species $S$. acanthias (e.g. Beamish and McFarlane, 1985) (Fig. 2B). The strong white band near the spine base was assumed to represent a check, probably characterizing the region of active enamel formation (Campana et al., 2006). The fact that the bands in many of the spines showed irregular spacing was usually ignored, similarly with an age study in S. acanthias, since growth does not necessarily proceed in an orderly manner (Ketchen, 1975). Spines were read with naked eye, under natural light three independent times by the same reader. To minimize any possible source of bias, these readings were performed with time distance of three months between them and without prior knowledge of the specimen's length, sex or the previous band counts. In 70 individuals both first and second dorsal fin spines were examined and age results were compared in order to decide whether to consider or not the first dorsal spine in cases where the second one was useless.

A measure of precision is a valuable means of assessing the relative difficulty of determining the age of a particular structure, of estimating the reproducibility of the age determinations or of comparing the skill level of one reader relative to that of others (Campana, 2001). With the aim to evaluate the consistency of the three independent age estimates, precision was calculated based on the coefficient of variation (CV; Chang, 1982) and the average percent error (APE; Beamish and Fournier, 1981). According to the obtained CV and APE indices, only the two last readings were considered. Consequently, when they differed by 1 yr the estimates were selected alternately, when they differed by 2 yrs the mean of the two readings was accepted, while when their difference exceeded 2 yrs the corresponding spines were excluded from subsequent analysis ( \pm 2 -yr criterion; Ketchen, 1975). The CV and APE indices were also used to test for consistency between the primary reader's age estimates from the first and the second dorsal fin spine in 70 individuals. Further, the effect of the reader's experience on the precision of aging was evaluated by comparing the age estimates of 70 second dorsal fin spines between the primary reader and a less experienced one, who had formerly been trained by the primary reader. Finally, age-bias plots were constructed using the means and the $95 \%$ confidence intervals of the age estimates per age class in order to assess the bias between the reader's age estimates (Campana et al., 1995).

Although both dorsal fin spines were removed from each specimen, when possible, the second spine was preferred over the first one whose tip tends to be more worn down leading to an underestimation of age (Cailliet and Goldman, 2004). The second spine is also greater in length than the first one and it can be read more easily (Ketchen, 1975). However, the first spine was used either when the second one was missing or it was difficult to read because of severe wear or blur, as well as for the confirmation of the bands counted in the second spine. When the first spine was missing and the second one was worn below the first growth band, Ketchen's (1975) method was applied for the age estimation. In Ketchen's correction curve we did not consider the spines whose diameter at the no wear point (sensu Ketchen, 1975) was greater than the mean diameter of the point where the first growth band was deposited $(\mathrm{FRBD}=1.70 \mathrm{~mm}$, present study).

\subsection{Growth modeling and longevity}

The von Bertalanffy growth function (VBGF) parameters were estimated separately for each sex according to the equation: $L_{t}=L_{\infty}\left[1-e^{-k\left(t-t_{0}\right)}\right]$, where $L_{t}$ is the predicted length at age $t$ in $\mathrm{mm}$, $L_{\infty}$ is the mean theoretical asymptotic length in $\mathrm{mm}, k$ is a growth rate parameter in $\mathrm{yr}^{-1}$ and $t_{0}$ is the theoretical age at zero length in yrs (Von Bertalanffy, 1938). The growth performance index was estimated using the equation: $\Phi^{\prime}=\log (k)+2 \log \left(L_{\infty}\right)$, where $L_{\infty}$ and

Table 1

Definition and abbreviations of the morphometric measurements used for the dorsal fin spines of Squalus blainville in the present study.

\begin{tabular}{|c|c|c|}
\hline Abbreviation - measurement & Definition & Reference \\
\hline TSL - total spine length & Distance between tip to spine base & Clarke and Irvine (2006) \\
\hline ESL - external spine length & Distance between tip to the point of the spine's entry into the flesh & Clarke and Irvine (2006) \\
\hline EBD - enamel base diameter & Spine diameter at the enamel base & Tribuzio et al. (2010) \\
\hline EBW - enamel base width & Spine width at the enamel base & present study \\
\hline$Y_{1} Y_{2}$ - diameter at no wear point & Spine diameter at the most distal point of no wear & Ketchen (1975) \\
\hline FRBD - first readable band diameter & Spine diameter at the point where the first band is deposited & Present study \\
\hline FRBL - first readable band length & Distance between tip to the point of the first band's deposition & Present study \\
\hline
\end{tabular}


$k$ are the VBGF parameters (Munro and Pauly, 1983; Pauly and Munro, 1984). Longevity was estimated by the maximum number of external band counts $\left(A_{\max }\right)$.

\subsection{Length-weight relationships and somatic indices}

Length-weight relationships were determined according to the equation: TW $=\alpha \mathrm{TL}^{b}$, where TW is the total weight in $\mathrm{g}$, TL is the total length in $\mathrm{mm}, \alpha$ is the intercept and $b$ is the slope of the regression. The gonadosomatic and hepatosomatic indices were calculated according to the equations: $\mathrm{GSI}=(\mathrm{GW} / \mathrm{EW}) \times 100$ and $\mathrm{HSI}=(\mathrm{LW} / \mathrm{EW}) \times 100$, respectively, where $\mathrm{GW}$ is the gonad weight, LW is the liver weight and EW is the eviscerated weight of the specimens, all recorded in $\mathrm{g}$. The condition factor was calculated as: $K=\left(\mathrm{EW} / \mathrm{TL}^{3}\right) \times 100$, where $\mathrm{EW}$ is the eviscerated weight in $\mathrm{g}$ and TL is the total length in $\mathrm{cm}$ (Ricker, 1975). The condition factor was also estimated based on previously reported length-weight equations of the studied species for comparison purposes.

\subsection{Length and age at first maturity}

For both females and males, sexual maturity was assessed according to the maturity scales reported by Kousteni and Megalofonou (2011). Given that as a mature specimen is considered the one that is able to reproduce or has done so in the past (Conrath, 2004), females and males belonging to stages I and II were considered as immature and the remaining ones as mature.

Length at $50 \%$ maturity $\left(L_{50}\right)$ was determined through the fitting of maturity ogives. The proportions of mature versus immature individuals within length classes of $10 \mathrm{~mm}$ were estimated for each sex. A logistic curve was fitted to the data and the length at which $50 \%$ of individuals are sexually mature, was calculated following the equation: $P_{i}=1 /\left[1+\mathrm{e}^{(\alpha+b T \mathrm{~L})}\right]$, where $P_{i}$ is the proportion of mature individuals in length class $i$, and $\alpha$ and $b$ are the fitted parameters, which can change during the life cycle (King, 1995). The length at $50 \%$ maturity was calculated as: $L_{50}=\alpha / b$ (Spare and Venema, 1992). In a similar way, a logistic model was fitted to the paired maturity and age data, and the age at which $50 \%$ of individuals are sexually mature $\left(T_{50}\right)$ was calculated following the equation: $P_{i}=1 /\left[1+\mathrm{e}^{(\alpha+b \text { Age })}\right]$.

\subsection{Statistical analyses}

Sex ratio was compared with the $1: 1$ proportion using the chi-squared test (Zar, 1999). Total length and age frequency distributions were represented by histograms. The slopes of the specimen's TL-TW regressions were tested against the isometric slope standard of 3 with the Student's t-test (Zar, 1999). Multiplicative regression analysis was used to describe the relationship between specimen's total length and spine morphometrics or spine weight. The level of significance for each pairwise correlation was estimated through the analysis of variance ANOVA (Zar, 1999). The analysis of covariance ANCOVA (Zar, 1999) was used to test for between-sex differences by comparing the slopes of the aforementioned regressions. The Student's $t$-test was used for between-sex comparisons of the mean values of the spine measurements and of the mean TL in each age class. Significant differences in the VBGF parameters between females and males were evaluated with likelihood ratio tests (Kimura, 1980). Descriptive statistics was assessed for the total length, weight and age of the specimens, the spine morphometrics, the precision indices and the three somatic indices. Parametric statistics was used to test for significant differences in the mean values of GSI, HSI and $K$ between sexes, between immature and mature individuals (Student's $t$-test), among seasons and among age classes (ANOVA). Frequency distributions, regression analysis and descriptive statistics were performed in MS EXCEL

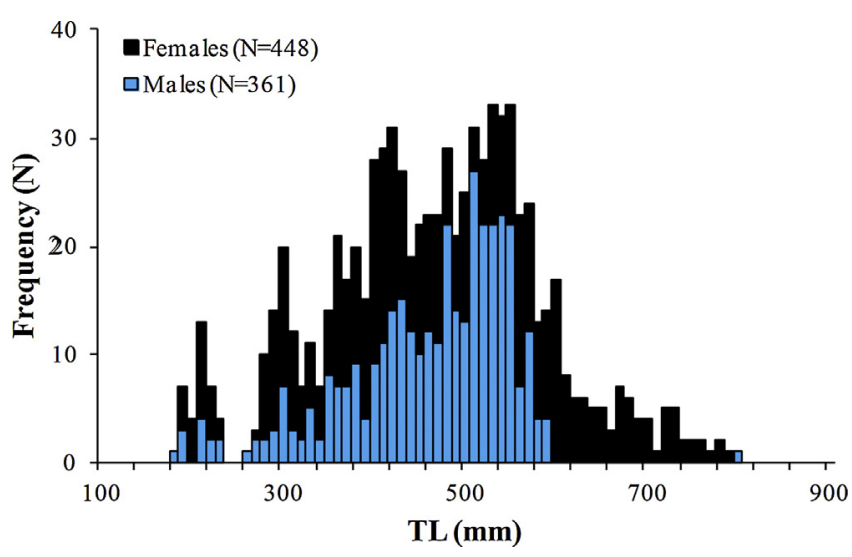

Fig. 3. Total length (TL) frequency distributions of female and male Squalus blainville in the eastern Mediterranean Sea.

2007, likelihood ratio tests were run in R v.2.13 ( $\mathrm{R}$ Development Core Team, 2009), and the rest of the statistical analyses were implemented in STATGRAPHICS v.16.2.

\section{Results}

\subsection{Sex ratio and length frequency distributions}

Females outnumbered males by a sex ratio of $1.24: 1$, which was significantly different from the $1: 1$ ratio $\left(\chi^{2}=4.69, P<0.05\right)$. Among all specimens one hermaphrodite was recorded. In females, TL ranged from 182 to $790 \mathrm{~mm}$ ( mean $=466 \pm 137$ ) and TW from 22 to $3000 \mathrm{~g}$ (mean $=666 \pm 603$ ). In males, TL ranged from 180 to $799 \mathrm{~mm}$ $($ mean $=456 \pm 90)$ and TW from 21 to $3079 \mathrm{~g}$ (mean $=486 \pm 270)$. Females dominated in higher length classes than males did (Fig. 3). However, the largest specimen caught was a male reaching $799 \mathrm{~mm}$ in TL. A total of 191 embryos were recorded ( 87 females, 75 males, 29 unsexed), ranging from 37 to $209 \mathrm{~mm}$ in $\mathrm{TL}$ (mean $=128 \pm 45.6$ ) and from 0.1 to $38.3 \mathrm{~g}$ in TW without the yolk sac weight (mean $=12.8 \pm 9.52$ ).

\subsection{Spine morphometry}

In juveniles/adults, no statistically significant between-sex differences were found in the mean values of all spine measurements, except EBW (Table 2). Spines were well-formed and present in all examined embryos, from the smallest $(69 \mathrm{~mm}$ of $\mathrm{TL})$ to the largest one ( $209 \mathrm{~mm}$ of $\mathrm{TL}$ ). At early stage of life spines were soft, flexible and difficult to remove, while in fully formed embryos spines were rigid. In any case, no growth band formation was observed, but the strong white band of enamel formation near the spine enamel base (Campana et al., 2006) was always apparent. Both morphometrics and weight of the spines showed no statistically significant difference between female and male embryos (Table 2).

In juveniles/adults and embryos, a statistically significant relationship was found between specimen's length and spine morphometrics or spine weight regardless the sex $\left(P_{\mathrm{ANOVA}}=0\right.$ in all cases). Comparing the slopes of the aforementioned regressions revealed statistically significant between-sex differences in TL-TSL, TL-ESL and TL-SW relationships in juveniles/adults $\left(P_{\text {ANCOVA }}<0.1\right)$, a pattern that was not observed in embryos (Table 3 ).

\subsection{Age estimates, reading precision and aging bias}

In total 685 spines (26 and 657 from the first and second dorsal fin, respectively) were removed from 810 individuals and were 
Table 2

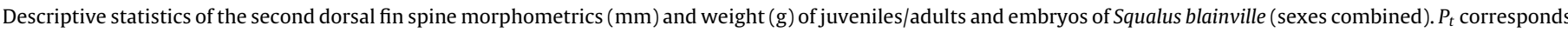

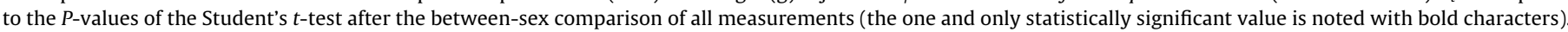

\begin{tabular}{|c|c|c|c|c|c|c|}
\hline Measurement & $N$ & Mean & SD & Min & Max & $P_{t}$ \\
\hline \multicolumn{7}{|c|}{ Juveniles and adults } \\
\hline TSL & 577 & 42.9 & 10 & 14.1 & 68.4 & 0.61 \\
\hline ESL & 596 & 32.0 & 7.99 & 10.9 & 58.8 & 0.73 \\
\hline EBD & 685 & 3.55 & 0.89 & 1.20 & 6.30 & 0.11 \\
\hline EBW & 684 & 2.99 & 0.69 & 1.08 & 4.85 & $9 E-06$ \\
\hline$Y_{1} Y_{2}$ & 382 & 0.69 & 0.39 & 0.10 & 2.10 & 0.13 \\
\hline FRAD & 654 & 1.70 & 0.19 & 0.97 & 2.80 & 0.67 \\
\hline FRAL & 547 & 11.5 & 1.79 & 5.06 & 16.3 & 0.20 \\
\hline SW & 590 & 0.30 & 0.18 & 0.02 & 1.17 & 0.12 \\
\hline \multicolumn{7}{|l|}{ Embryos } \\
\hline TSL & 55 & 9.09 & 3.91 & 2.32 & 18.7 & 0.71 \\
\hline ESL & 52 & 5.07 & 2.50 & 1.42 & 11.7 & 0.91 \\
\hline EBD & 55 & 0.67 & 0.30 & 0.20 & 1.75 & 0.96 \\
\hline EBW & 41 & 0.70 & 0.30 & 0.28 & 1.20 & 0.72 \\
\hline SW & 52 & 0.0038 & 0.006 & 0.0001 & 0.032 & 0.87 \\
\hline
\end{tabular}

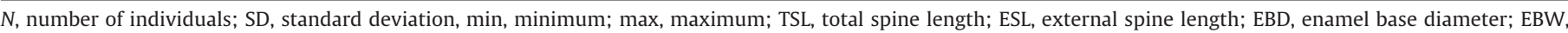
enamel base width; $Y_{1} Y_{2}$, diameter at no wear point; FRBD, first readable band diameter; FRBL, first readable band length; SW, spine weight.

all included in the three successive age estimates of the primary reader. In the remaining ones both first and second dorsal fin spines were either missing $(N=90)$ or severely broken baring a tiny part of dentin but no enamel $(N=35)$.

The obtained CV and APE precision indices, confirmed a high precision of the two last readings of the primer reader (Table 4), so these were considered. Further comparisons of counts between the first and the second dorsal fin spine $(C V=7.1 \%, A P E=5 \%)$ showed that the first spine can be as well considered in aging calculation (Table 5). Moreover, in $63 \%$ of the spines examined by the different readers the aging results met the \pm 2 -yr criterion (Table 5) and the pairwise comparison of counts indicated relatively high precision ( $\mathrm{CV}=11.2 \%$ and $\mathrm{APE}=7.9 \%$ ). Age bias plots also revealed no appreciable bias between the counts of the two readers (Fig. 4).

Counting the bands at the external surface of the dorsal fin spines was proved to be a quite difficult process, requiring a great deal of time and effort for the examination of each spine at many angles under natural light. The difficulty in assessing the species' age is also reflected to the fact that 569 out of the 810 collected specimens were eventually aged and included in growth analysis, out of which 20 were aged from the first dorsal fin spine, 547 from the second one and 2 were aged according to Ketchen (1975).

\subsection{Ketchen's correction curve}

Two large females ( 727 and $759 \mathrm{~mm}$ of TL), baring only severely broken second spines, were aged by reconstructing Ketchen's correction curve in which 546 second dorsal fin spines were considered $(\mathrm{EBD}=3.4 \pm 0.9$, range $=1.2-6.3 \mathrm{~mm})$. Given that no statistically significant difference was found in the mean EBD between females and males $\left(P_{t}<0.05\right)$, sexes were combined in this curve. According to the modified correction curve for the longnose spurdog in the eastern Mediterranean Sea: Age $=0.5634 \mathrm{EBD}^{2.343}$ (Fig. 5), the final estimated age of the specimens was 27 and 19 yrs, respectively.

With the scope to examine the precision of Ketchen' method, in 20 individuals whose age was assessed from the first spine, age was also estimated from their broken second spines wherever they existed $\left(Y_{1} Y_{2}=2.93 \pm 0.56\right.$, range $\left.=2.2-4.1 \mathrm{~mm}, N=13\right)$. The results showed that the difference in years between the observed growth bands from the first spine and the calculated age from the broken spines equalled 0,1 and 2 yrs in 5, 2 and 6 individuals, respectively, all meeting the \pm 2 -yr criterion.

\subsection{Age frequency distribution}

Out of the 569 individuals that were included in growth analysis, 314 were females ranging from 182 to $759 \mathrm{~mm}$ of TL (mean

Table 3

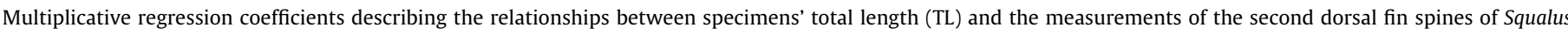

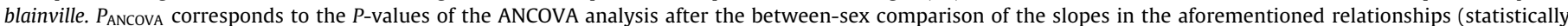
significant values are noted with bold characters).

\begin{tabular}{|c|c|c|c|c|c|c|c|c|c|c|c|}
\hline \multirow[t]{2}{*}{$X-Y$} & \multicolumn{5}{|c|}{ Females } & \multicolumn{5}{|c|}{ Males } & \multirow[t]{2}{*}{$P_{\text {ANCOVA }}$} \\
\hline & $N$ & $\ln (a)$ & $b$ & $\mathrm{SE}(b)$ & $R^{2}$ & $N$ & $\ln (a)$ & $b$ & $\mathrm{SE}(b)$ & $R^{2}$ & \\
\hline \multicolumn{12}{|c|}{ Juveniles and adults } \\
\hline TL-TSL & 320 & -1.52 & 0.87 & 0.015 & 0.91 & 257 & -1.80 & 0.91 & 0.020 & 0.90 & 0.03 \\
\hline TL-ESL & 331 & -2.29 & 0.94 & 0.015 & 0.92 & 265 & -2.65 & 1.00 & 0.020 & 0.91 & 0.02 \\
\hline TL-EBD & 383 & -4.51 & 0.95 & 0.012 & 0.94 & 302 & -4.56 & 0.95 & 0.018 & 0.91 & 0.50 \\
\hline TL-EBW & 383 & -3.91 & 0.82 & 0.013 & 0.91 & 301 & -4.07 & 0.84 & 0.018 & 0.88 & 0.44 \\
\hline $\mathrm{TL}-\mathrm{Y}_{1} \mathrm{Y}_{2}$ & 198 & -9.96 & 1.51 & 0.169 & 0.29 & 184 & -9.60 & 1.46 & 0.270 & 0.14 & 0.86 \\
\hline TL-SW & 329 & -17.50 & 2.64 & 0.029 & 0.96 & 261 & -18.20 & 2.77 & 0.038 & 0.95 & 0.01 \\
\hline \multicolumn{12}{|l|}{ Embryos } \\
\hline TL-TSL & 35 & -7.35 & 1.96 & 0.083 & 0.94 & 20 & -6.13 & 1.71 & 0.137 & 0.90 & 0.13 \\
\hline TL-ESL & 32 & -8.97 & 2.16 & 0.120 & 0.92 & 20 & -9.91 & 2.34 & 0.210 & 0.87 & 0.40 \\
\hline TL-EBD & 35 & -8.85 & 1.74 & 0.100 & 0.91 & 20 & -7.73 & 1.50 & 0.180 & 0.80 & 0.24 \\
\hline TL-EBW & 24 & -9.55 & 1.89 & 0.150 & 0.88 & 17 & -8.56 & 1.69 & 0.170 & 0.87 & 0.41 \\
\hline TL-SW & 33 & -36.90 & 6.28 & 0.360 & 0.90 & 19 & -38.90 & 6.67 & 0.520 & 0.90 & 0.58 \\
\hline
\end{tabular}

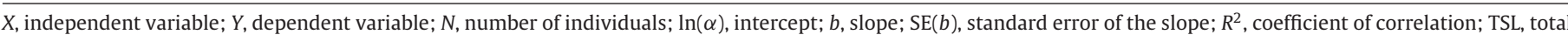
spine length; ESL, external spine length; EBD, enamel base diameter; EBW, enamel base width; $Y_{1} Y_{2}$, diameter at no wear point; SW, spine weight. 
Table 4

Mean value $( \pm S D)$ of the precision indices for each pairwise comparison of the three independent age estimates by the primary reader.

\begin{tabular}{|c|c|c|c|c|}
\hline \multirow[t]{2}{*}{ Precision indices } & \multicolumn{4}{|c|}{ Primary reader's age estimates } \\
\hline & 1st vs 2nd & 1 st vs 3rd & 2nd vs 3rd & 1 st vs 2 nd vs 3 rd \\
\hline Coefficient of variation (CV\%) & $18.2 \pm 15.6$ & $23.6 \pm 17.0$ & $8.00 \pm 8.7$ & $19.9 \pm 14.2$ \\
\hline Average percent error (APE\%) & $12.9 \pm 11.0$ & $16.7 \pm 12.0$ & $5.70 \pm 6.2$ & $14.9 \pm 10.7$ \\
\hline
\end{tabular}

Table 5

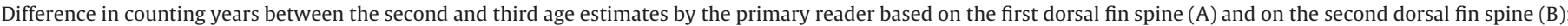

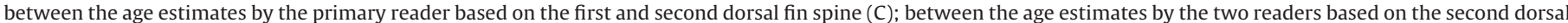
fin spine (D). The horizontal dashed line corresponds to the upper accepted limit in pairwise age differences ( \pm 2 -yr criterion; Ketchen, 1975).

\begin{tabular}{|c|c|c|c|c|c|c|c|c|}
\hline \multirow[t]{3}{*}{ Diferrence (yrs) } & \multirow{2}{*}{\multicolumn{2}{|c|}{1 st spine $(N=26)$}} & \multirow{2}{*}{\multicolumn{2}{|c|}{$\frac{\mathrm{B}}{\text { 2nd spine }(N=657)}$}} & \multirow{2}{*}{\multicolumn{2}{|c|}{$\frac{\mathrm{C}}{1 \text { st vs 2nd spine }(N=70)}$}} & \multicolumn{2}{|l|}{$\mathrm{D}$} \\
\hline & & & & & & & \multicolumn{2}{|c|}{1 st vs 2 nd reader $(N=70)$} \\
\hline & $N$ & $\%$ & $N$ & $\%$ & $N$ & $\%$ & $N$ & $\%$ \\
\hline 0 & 8 & 30.8 & 215 & 32.7 & 23 & 32.9 & 12 & 17.1 \\
\hline 1 & 6 & 23.1 & 233 & 35.5 & 24 & 34.3 & 14 & 20.0 \\
\hline 2 & 6 & 23.1 & 99 & 15.1 & 13 & 18.6 & 18 & 25.7 \\
\hline 3 & 1 & 3.85 & 55 & 8.37 & 4 & 5.71 & 19 & 27.1 \\
\hline 4 & 4 & 15.4 & 33 & 5.02 & 3 & 4.29 & 3 & 4.29 \\
\hline 5 & 1 & 3.85 & 12 & 1.83 & 2 & 2.86 & 2 & 2.86 \\
\hline 6 & 0 & 0 & 6 & 0.91 & 1 & 1.43 & 1 & 1.43 \\
\hline 7 & 0 & 0 & 1 & 0.15 & 0 & 0 & 1 & 1.43 \\
\hline 8 & 0 & 0 & 1 & 0.15 & 0 & 0 & 0 & 0 \\
\hline 9 & 0 & 0 & 1 & 0.15 & 0 & 0 & 0 & 0 \\
\hline 10 & 0 & 0 & 1 & 0.15 & 0 & 0 & 0 & 0 \\
\hline
\end{tabular}
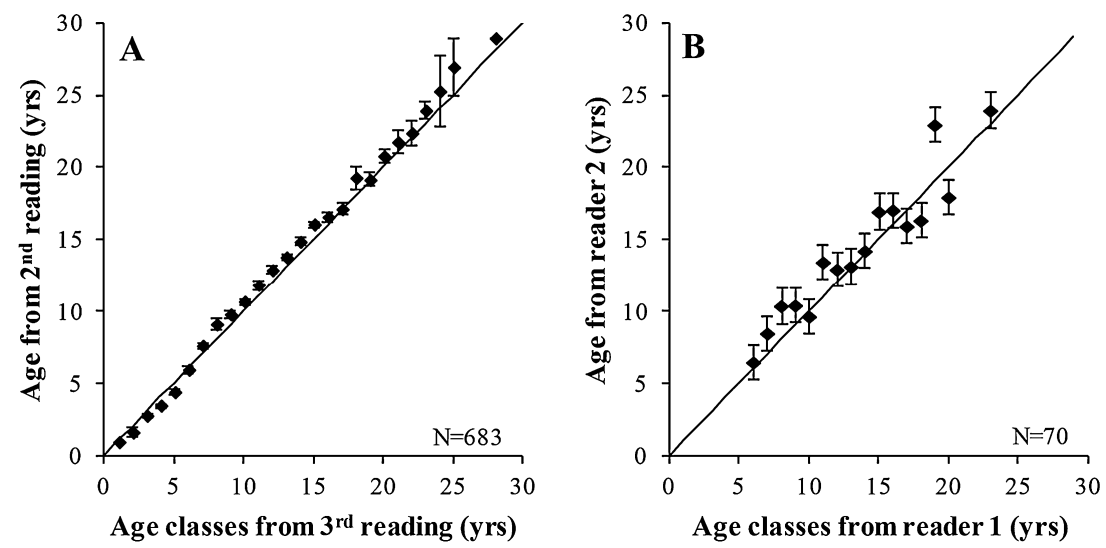

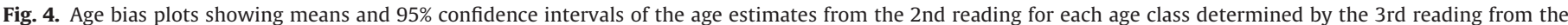

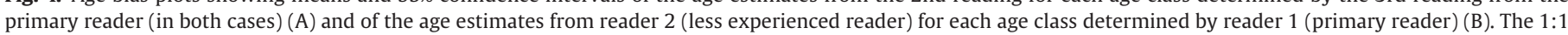
equivalence (straight line) is indicated in both graphs.

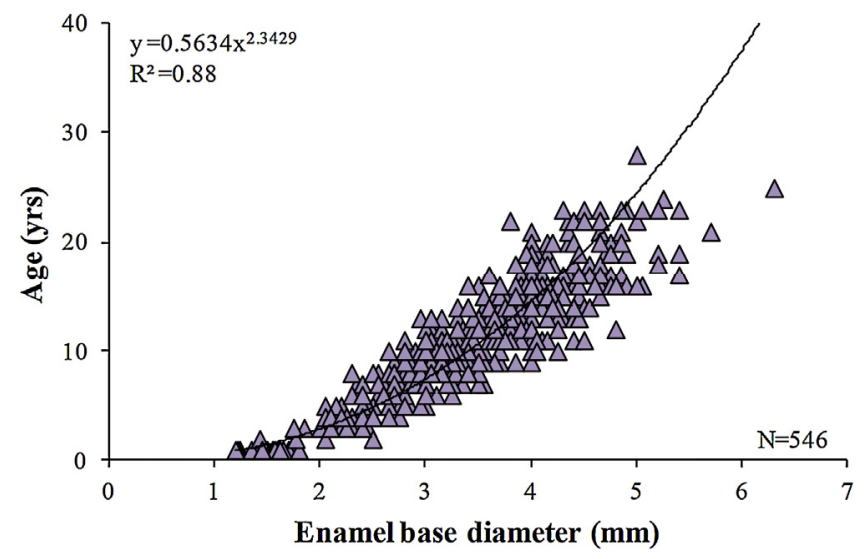

Fig. 5. Modified Ketchen's correction curve for Squalus blainville (sexes combined) in the eastern Mediterranean Sea. age $=11.1 \pm 5.9$, range $=1-28$ yrs), 254 were males ranging from 180 to $589 \mathrm{~mm}$ of TL (mean age $=11.1 \pm 4.5$, range $=1-22 \mathrm{yrs}$ ) and one was hermaphrodite reaching $522 \mathrm{~mm}$ of TL and 19 yrs (Fig. 6). In general, no significant differences were found in the mean TL between sexes in all age classes, except 6, 9, 10, 18 and 19 yrs. Differences in the mean TL between sexes were not tested for the classes of 2 and 20-28 yrs because of inadequate samples (Table 6).

\subsection{Growth parameters and longevity}

The VBGF parameters were: $L_{\infty}=1097.3 \mathrm{~mm}, k=0.03 \mathrm{yr}^{-1}$ and $t_{0}=-5.6$ yrs for females, and $L_{\infty}=665.5 \mathrm{~mm}, k=0.08 \mathrm{yr}^{-1}$ and $t_{0}=-3.4$ yrs for males (Fig. 7). Likelihood ratios revealed that all growth parameters were statistically significantly different between sexes $\left(\chi^{2}=38.26, d f=3, P<0.001\right)$. The growth performance index $\left(\Phi^{\prime}\right)$ was 4.56 and 4.55 for females and males, respectively. The oldest female and male reached 28 yrs $(678 \mathrm{~mm}$ of $\mathrm{TL}$ ) and 22 yrs ( $474 \mathrm{~mm}$ of $\mathrm{TL}$ ), respectively. The largest female and male that were aged, reached $759 \mathrm{~mm}$ (19 yrs) and $589 \mathrm{~mm}$ (16 


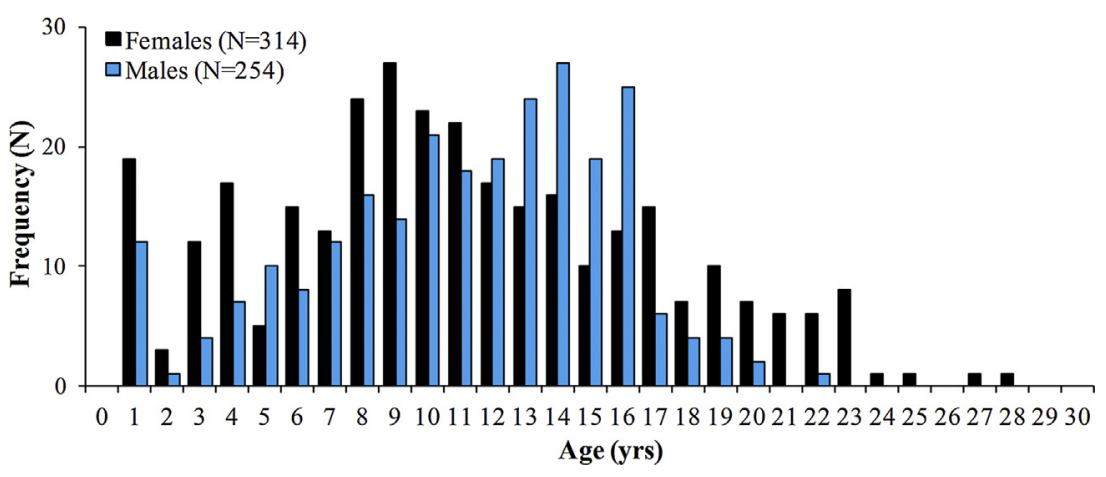

Fig. 6. Age frequency distributions of female and male Squalus blainville in the eastern Mediterranean Sea.

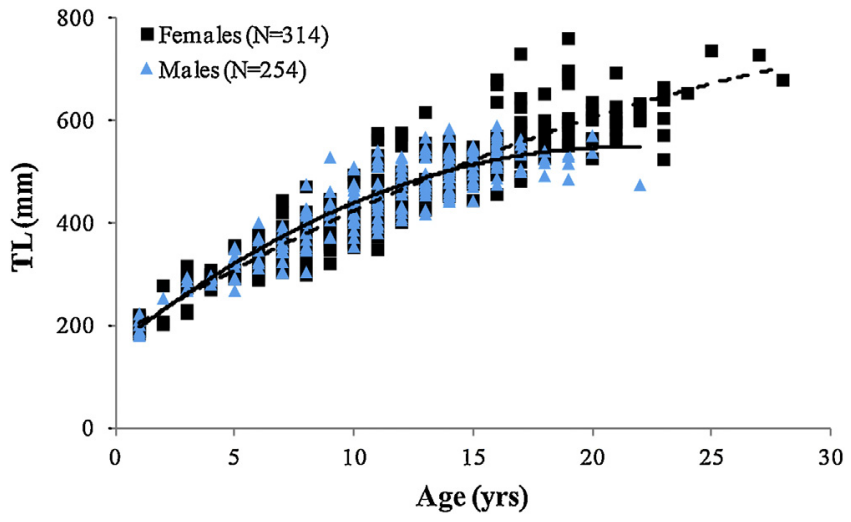

Fig. 7. Growth curves fitted to the observed length-at-age data for female (dashed line) and male (solid line) Squalus blainville in the eastern Mediterranean Sea. yrs), respectively. Although few females exceeding $700 \mathrm{~mm}$ were managed to be aged, the only large male reaching $799 \mathrm{~mm}$ was impossible to age because its spines were missing. For the same reason the largest female ( $790 \mathrm{~mm}$ of TL) was not aged either. Even that the sample size was large and included large and probably very old individuals, it was impossible to age them because of their missing or severely broken spines. According to the above, the actual longevity of the species, and especially of male individuals, may have been underestimated.

\subsection{Length-weight relationships and somatic indices}

The length-weight relationships were described by the equations: TW $=7 \mathrm{E}-07 \mathrm{TL}^{3.32}\left(R^{2}=0.99, N=445\right)$ in females and TW=2E-06TL $3.16\left(R^{2}=0.98, N=361\right)$ in males (Fig. 8). Examining the length-weight relationships revealed positive allometric growth for both sexes $\left(P_{t}<0.05\right)$, as well as sexual size dimorphism, since statistically significant differences were found between both the slopes and the intercepts $\left(P_{\mathrm{ANCOVA}}<0.05\right)$.

Table 6

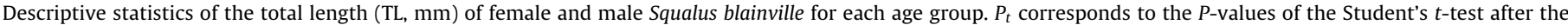
between-sex comparison of the mean TL for each age class (statistically significant values are noted with bold characters).

\begin{tabular}{|c|c|c|c|c|c|c|c|c|c|c|c|}
\hline \multirow[t]{2}{*}{ Age (yrs) } & \multicolumn{5}{|c|}{ Females } & \multicolumn{5}{|c|}{ Males } & \multirow[t]{2}{*}{$P_{t}$} \\
\hline & $N$ & Mean & SD & Min & Max & $N$ & Mean & SD & Min & Max & \\
\hline 1 & 19 & 202.1 & 10.6 & 182 & 220 & 12 & 201.6 & 14.6 & 180 & 223 & 0.91 \\
\hline 2 & 3 & 228.0 & 42.5 & 201 & 277 & 1 & 253.0 & & & & \\
\hline 3 & 12 & 276.1 & 26.4 & 223 & 315 & 4 & 280.3 & 12.3 & 268 & 294 & 0.77 \\
\hline 4 & 17 & 288.7 & 9.91 & 269 & 307 & 7 & 291.3 & 5.71 & 280 & 297 & 0.53 \\
\hline 5 & 5 & 319.8 & 30.6 & 290 & 355 & 10 & 318.4 & 27.2 & 268 & 352 & 0.93 \\
\hline 6 & 15 & 324.8 & 26.0 & 288 & 375 & 8 & 351.3 & 30.0 & 312 & 400 & 0.04 \\
\hline 7 & 13 & 354.2 & 44.0 & 303 & 443 & 12 & 348.8 & 28.1 & 303 & 394 & 0.72 \\
\hline 8 & 24 & 380.4 & 40.9 & 298 & 470 & 16 & 393.9 & 42.3 & 304 & 475 & 0.32 \\
\hline 9 & 27 & 394.4 & 32.3 & 320 & 446 & 14 & 426.3 & 37.8 & 371 & 528 & 0.01 \\
\hline 10 & 23 & 402.2 & 34.7 & 351 & 493 & 21 & 433.0 & 40.8 & 354 & 509 & 0.01 \\
\hline 11 & 22 & 451.3 & 61.5 & 347 & 574 & 18 & 448.5 & 48.5 & 380 & 541 & 0.88 \\
\hline 12 & 17 & 465.8 & 55.3 & 400 & 575 & 19 & 471.6 & 41.5 & 405 & 529 & 0.72 \\
\hline 13 & 15 & 491.3 & 52.6 & 424 & 615 & 24 & 495.9 & 41.0 & 417 & 567 & 0.76 \\
\hline 14 & 16 & 499.7 & 38.0 & 451 & 558 & 27 & 503.5 & 39.3 & 442 & 583 & 0.46 \\
\hline 15 & 10 & 505.0 & 31.5 & 443 & 548 & 19 & 516.5 & 31.7 & 443 & 550 & 0.36 \\
\hline 16 & 13 & 557.4 & 67.3 & 455 & 679 & 25 & 536.0 & 27.4 & 475 & 589 & 0.17 \\
\hline 17 & 15 & 574.5 & 61.6 & 481 & 729 & 6 & 532.2 & 25.3 & 500 & 563 & 0.12 \\
\hline 18 & 7 & 575.3 & 41.2 & 525 & 651 & 4 & 518.5 & 20.1 & 492 & 540 & 0.03 \\
\hline 19 & 10 & 627.9 & 71.0 & 550 & 759 & 4 & 516.3 & 22.2 & 485 & 534 & 0.01 \\
\hline 20 & 7 & 587.0 & 38.7 & 525 & 635 & 2 & 553.5 & 23.3 & 537 & 570 & ${ }^{*}$ \\
\hline 21 & 6 & 610.2 & 45.3 & 563 & 692 & 0 & & & & & * \\
\hline 22 & 6 & 614.2 & 14.9 & 598 & 632 & 1 & 474.0 & & & & $*$ \\
\hline 23 & 8 & 619.1 & 50.0 & 523 & 664 & 0 & & & & & * \\
\hline 24 & 1 & 652.0 & & & & 0 & & & & & ${ }^{*}$ \\
\hline 25 & 1 & 735.0 & & & & 0 & & & & & * \\
\hline 26 & 0 & & & & & 0 & & & & & * \\
\hline 27 & 1 & 727.0 & & & & 0 & & & & & * \\
\hline 28 & 1 & 678.0 & & & & 0 & & & & & $*$ \\
\hline
\end{tabular}

$N$, number of individuals; SD, standard deviation, min, minimum; max, maximum.

* The statistical test was not run in these age classes due to inadequate samples 


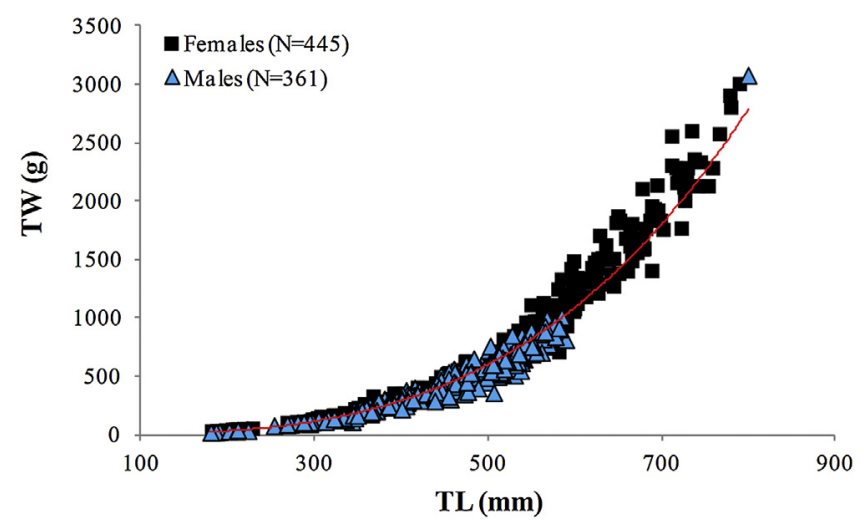

Fig. 8. Length-weight relationships of female and male Squalus blainville in the eastern Mediterranean Sea. The red line corresponds to the TL-TW relationship for sexes combined. (For interpretation of the references to color in this figure legend, the reader is referred to the web version of this article.)

Gonadosomatic and hepatosomatic indices reached higher values in females (GSI $=1.34 \pm 2.28$ and $\mathrm{HSI}=9.97 \pm 4.58$ ) than males (GSI $=0.90 \pm 0.66$ and $\mathrm{HSI}=9.59 \pm 3.24$ ), while the condition factor showed low values in both sexes $(K=0.38 \pm 0.05$ in females and $K=0.37 \pm 0.04$ in males) (Fig. 9). Between the two sexes, statistically significant differences were found in mean GSI $\left(P_{t}<0.05\right)$, but not in mean $\operatorname{HSI}\left(P_{t}=0.1989\right)$ or mean $K\left(P_{t}=0.1779\right)$. Considering only the mature individuals, statistically significant differences were found between females and males in mean GSI, HSI and $K$ in every season of the year $\left(P_{t}<0.05\right)$, except in mean $K$ during winter $\left(P_{t}=0.0824\right)$. On the other hand, considering only the immature individuals, statistically significant between-sex differences were not found in any of the indices $\left(P_{t}\right.$ range $\left.=0.0625-0.9854\right)$, except in mean GSI during autumn $\left(P_{t}<0.05\right)$. Statistically significant differences were also found in mean GSI, HSI and $K$ either between mature and immature individuals $\left(P_{t}<0.05\right)$ or from one season to another $\left(P_{\text {ANOVA }}<0.05\right)$ in each sex (Fig. 9).

A clear evolution for all indices was observed as specimens, regardless their sex, grew old, showing statistically significant differences among the various age classes $\left(P_{\text {ANOVA }}<0.05\right)$. Examining the variation in mean $K$ among the different age classes revealed that it was gradually increasing in the first years of life in both sexes and after a time, at about 11 yrs for females and 7 yrs for males, it was stabilizing. Similarly, mean GSI was significantly low in the first years of life and started to increase as the species grew older. On the other hand, mean HSI was gradually decreasing during the first years of life and after almost 5-6 yrs it started increasing in both sexes (Fig. 10).

\subsection{Length and age at first maturity}

Males attained maturity at smaller size and age than females (Table 7). The smallest mature female was $523 \mathrm{~mm}$ of TL, $770 \mathrm{~g}$ of TW and 23 yrs old, while the smallest mature male was $420 \mathrm{~mm}$ of TL, $270 \mathrm{~g}$ of TW and $8 \mathrm{yrs}$ old. At lengths greater than $652 \mathrm{~mm}$ all females were mature, while all males were mature at lengths greater than $490 \mathrm{~mm}$. $L_{50}$ was estimated at $568.1 \mathrm{~mm}$ for females and $460.6 \mathrm{~mm}$ for males, while $T_{50}$ was 17.03 and 11.31 yrs for females and males, respectively (Fig. 11).

\section{Discussion}

The age and growth of the longnose spurdog S. blainville from the eastern Mediterranean Sea were assessed by examining for the first time the external surface of the dorsal fin spines. The thorough
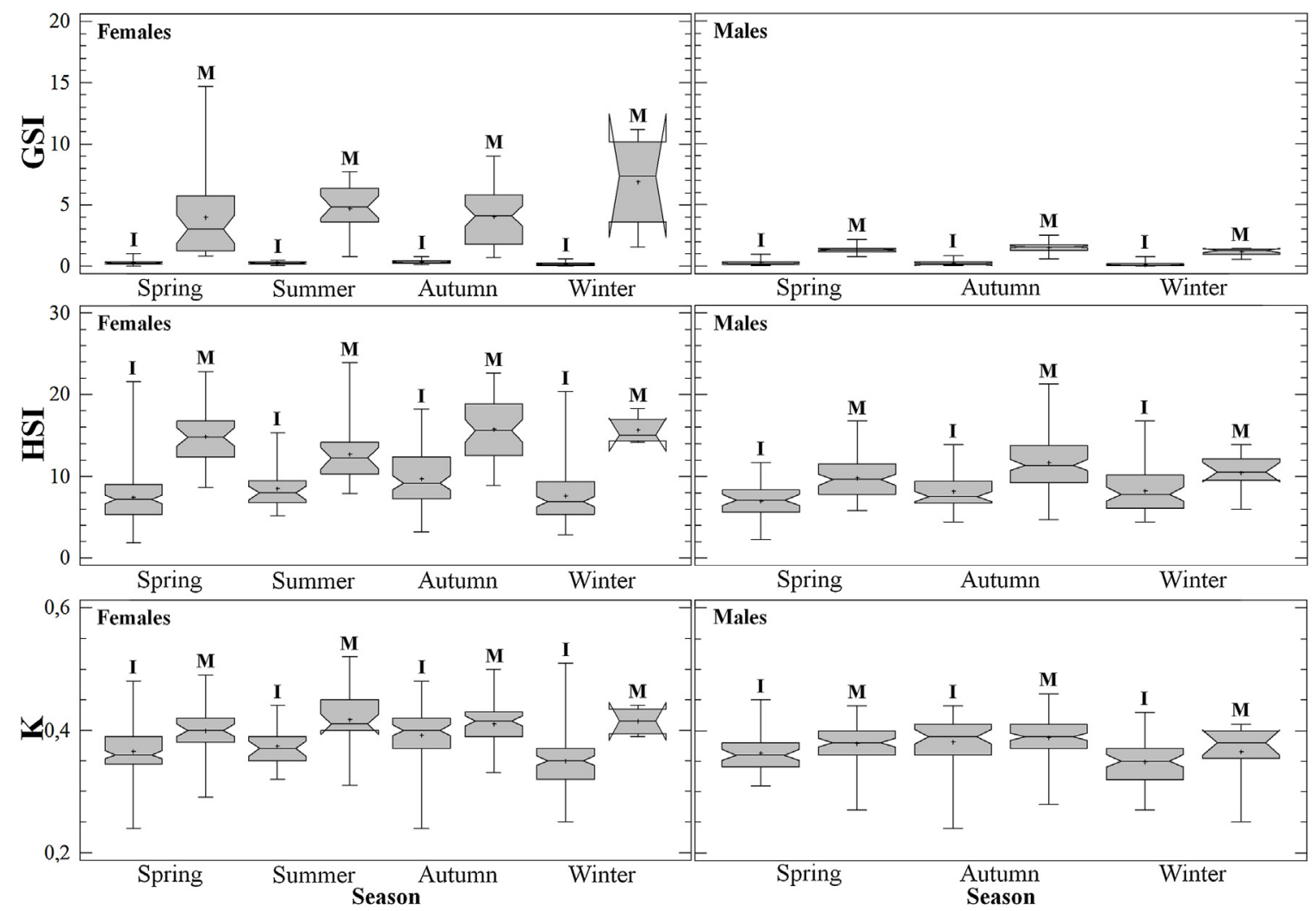

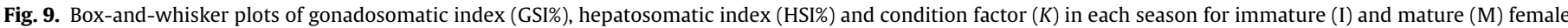

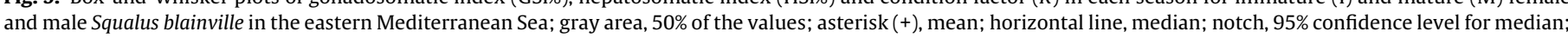
vertical lines, minimum and maximum. 


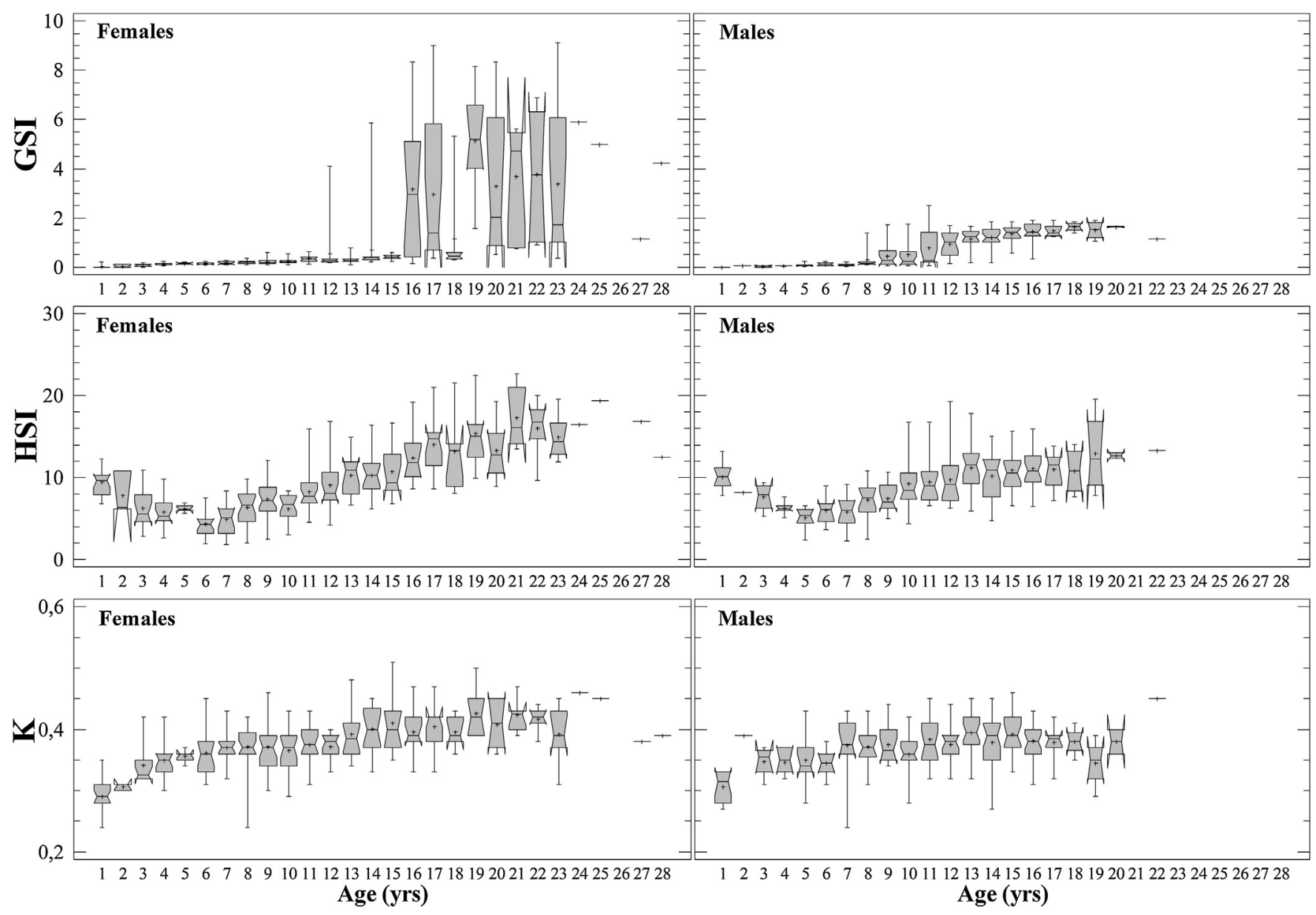

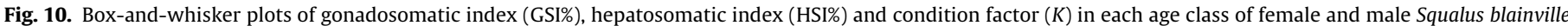

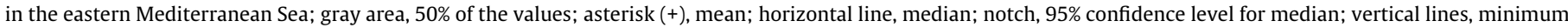
and maximum.

study of the species' spines revealed a great variability in the shape, spacing and darkness of the growth bands, as it was previously noticed in the co-generic species S. acanthias (Ketchen, 1975; Demirhan et al., 2006). In fact, aging S. blainville, involved a continuous learning process where inevitably the interpretation of banding patterns was somewhat subjective and improved with experience and time, reinforcing at the same time the need for validation.

\subsection{Spine morphometry and growth}

Prior to the external band counting, spine growth was examined by measuring its morphometrics as recommended by Clarke and Irvine (2006). Significant relationships were found between specimen's size and spine morphometrics or weight in both juveniles/adults and embryos, confirming the positive relationship

Table 7

Number (N), percentage (\%), age (yrs) and TL (mm) range of female and male Squalus blainville in each maturity stage proposed by Kousteni and Megalofonou (2011).

\begin{tabular}{|c|c|c|c|c|c|c|}
\hline \multirow[t]{2}{*}{ Stage } & \multicolumn{3}{|c|}{$\mathrm{TL}(\mathrm{mm})$} & \multicolumn{3}{|c|}{ Age (yrs) } \\
\hline & $\mathrm{N}$ & $\%$ & Range & $\mathrm{N}$ & $\%$ & Range \\
\hline \multicolumn{7}{|c|}{ Females } \\
\hline I & 259 & 60.4 & $182-651$ & 214 & 69.0 & $1-18$ \\
\hline II & 56 & 13.1 & $392-616$ & 38 & 12.3 & $8-23$ \\
\hline III & 26 & 6.1 & 529-618 & 16 & 5.2 & $12-21$ \\
\hline IV & 12 & 2.8 & $523-718$ & 6 & 1.9 & $13-23$ \\
\hline V & 10 & 2.3 & $564-727$ & 5 & 1.6 & $17-27$ \\
\hline VI & 53 & 12.4 & $560-779$ & 24 & 7.7 & $16-28$ \\
\hline VII & 13 & 3.0 & $555-759$ & 7 & 2.3 & $16-22$ \\
\hline Total & 429 & & $182-779$ & 310 & & $1-28$ \\
\hline \multicolumn{7}{|l|}{ Males } \\
\hline I & 132 & 38.0 & $180-472$ & 109 & 42.9 & $1-14$ \\
\hline II & 22 & 6.3 & $410-489$ & 13 & 5.1 & $9-16$ \\
\hline III & 82 & 23.6 & $420-576$ & 62 & 24.4 & $8-19$ \\
\hline IV & 111 & 32.0 & $445-799$ & 70 & 27.6 & $9-22$ \\
\hline Total & 347 & & $180-799$ & 254 & & $1-22$ \\
\hline
\end{tabular}



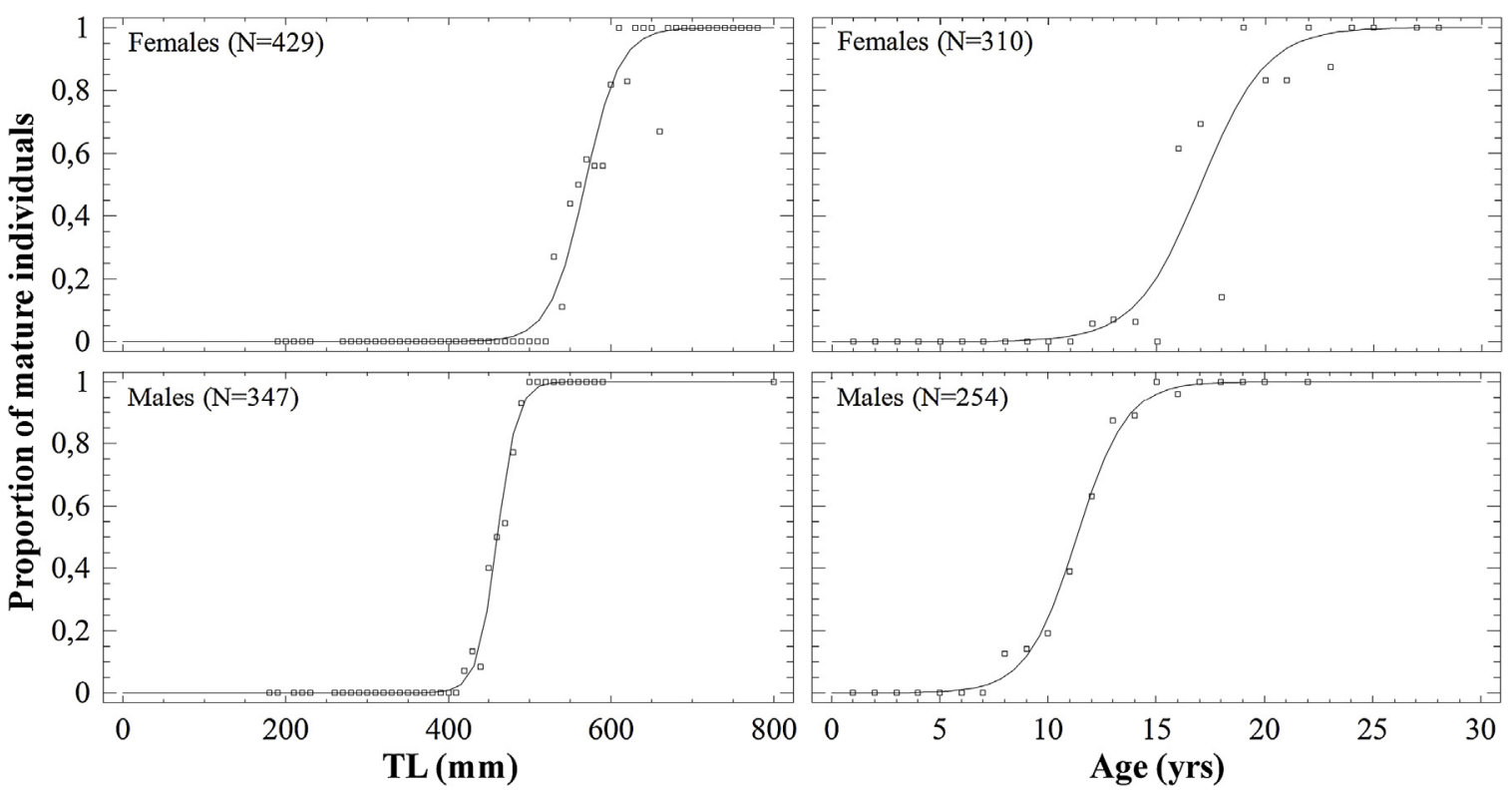

Fig. 11. Proportion of mature toward immature female and male Squalus blainville in each class of total length (left) and age (right) in the eastern Mediterranean Sea.

between specimen's and spine growth, an assumption that has to be fulfilled so that these structures can be considered in age estimates (Clarke and Irvine, 2006). Similar results were also found in Centroselachus crepidater (Irvine et al., 2006b), Etmopterus pusillus (Coelho and Erzini, 2007), Deania calceus (Clarke et al., 2002b) and Squalus megalops (Pajuelo et al., 2011). However, the fact that spine continues to grow throughout the shark's life does not mean by itself that this structure would represent its age. Actually, this is related to the fact that in several cases spines of larger size possessed fewer external growth bands than the smaller ones, as well as to the non linearity observed between specimen's size and spine measurements (Fig. 12). However, a validation of the structure used would confirm this assumption.

Spine growth was found to be most rapid in TL classes between 180 and $300 \mathrm{~mm}$ (Fig. 12), corresponding to the size after birth (Kousteni and Megalofonou, 2011). This rapid growth, which was also reflected to the observed large spacing between the first growth bands, could be associated with the defense strategy of the species, especially during the vulnerable juvenile stages.

The statistically significant between-sex differences that were revealed for the relationships TL-TSL, TL-ESL and TL-SW in juveniles/adults may support the hypothesis that there is a sexual dimorphism as far as spine length and weight are concerned. Similarly in C. crepidater the TL-TSL relationship differed significantly between sexes (Irvine et al., 2006b). Probably larger spines in males are an evolutionary adaptation for triggering females during mating (Pratt and Carrier, 2005).

\subsection{Verifying the accuracy of aging results}

Till present the annual formation of the growth bands on the surface of the spines has been validated in S. megalops through marginal increment analysis (MIR) (Pajuelo et al., 2011) and in $S$. acanthias through either the analysis of mark-recapture data (Beamish and McFarlane, 1985; McFarlane and Beamish, 1987) or bomb radiocarbon analysis (Campana et al., 2006). All methods confirmed that the broader light-colored band is deposited during summer and the darker one during winter (Tucker, 1985; Beamish and McFarlane, 1985).

A validation of an absolute age is equivalent to determining the accuracy of an age estimate (Campana, 2001) and it should be performed for each species separately (Beamish and McFarlane, 1983). The MIR analysis is one of the most commonly applied methods for validating annual growth band deposition on either vertebrae (Simpfendorfer, 1993; Conrath et al., 2002; Bubley et al., 2012) or spines (Coelho and Erzini, 2007, 2008, 2010; Pajuelo et al., 2011) in squalid sharks. However, the MIR analysis, which validates the periodicity of band formation in the size classes sampled at year-round basis (Cotton et al., 2014), is not considered one of the most accurate validating methods and is mainly suited to fastgrowing and/or young fish (Campana, 2001). It is further unsuitable for validating the external increments of spines, because their banding pattern consists of ridges rather than dark/light growth rings (Irvine et al., 2006a). According to the above and given the inadequate sampling of longnose spurdogs throughout the year, the MIR analysis was not applied for the validation of the aging structures used in the present study. On the other hand, although the radiochemical dating may offer the highest level of precision and is well suited to long-lived fish (Campana, 2001), its high cost and more importantly the observed longevity of the species of interest posed great limitations in its application. The present study was based on the assumption that the external enamel bands on S. blainville's spines are annual, given that the same structures have been validated by several methods in other species of the same group of sharks (Beamish and McFarlane, 1985; Campana et al., 2006; Pajuelo et al., 2011).

In our study the obtained precision indices were considered acceptable and ascertained the accuracy of the adopted aging procedure. Moreover, the low level of disagreement found in the countable bands between the first and second dorsal fin spines showed that the first spine can be equally considered in age analysis. A reasonable degree of precision was also produced by the comparisons between the first and second dorsal fin spines in $C$. squamosus (Clarke et al., 2002a), while both spines produced similar age results in D. calceus (Clarke et al., 2002b) and in S. megalops (Pajuelo et al., 2011). On the other hand, the precision indices had higher values after comparing the age estimates between the two readers, showing that experience can affect the precision of aging results. Age bias plots indicated no significant intraand small inter-reader variation. Overall, the current age determination of $S$. blainville seems to be more precise than those for other sharks where the same aging technique was applied. For 


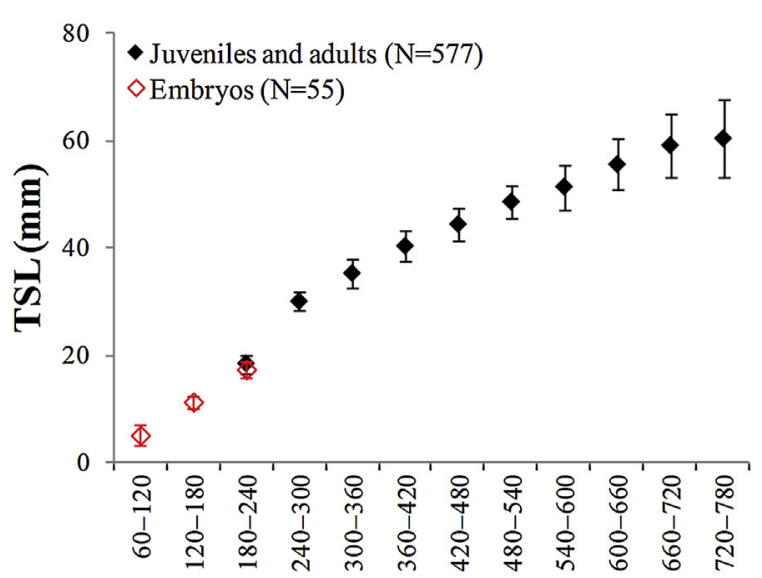

TL (mm)

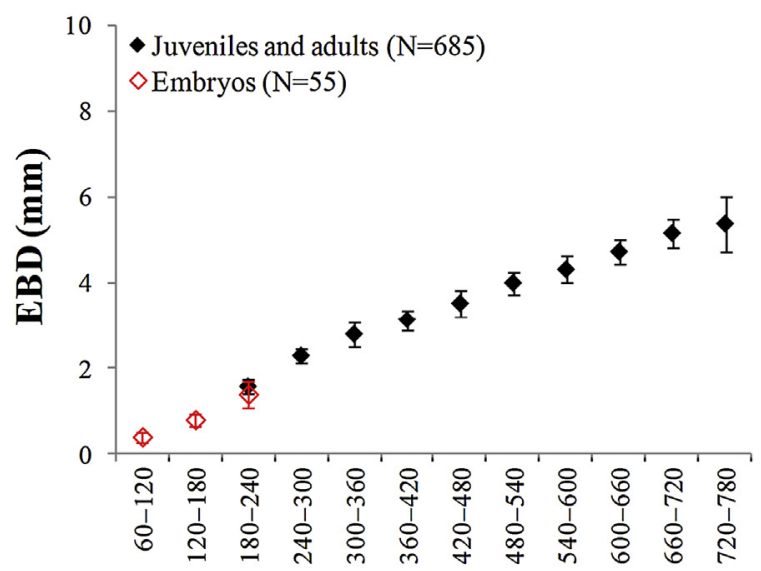

TL (mm)

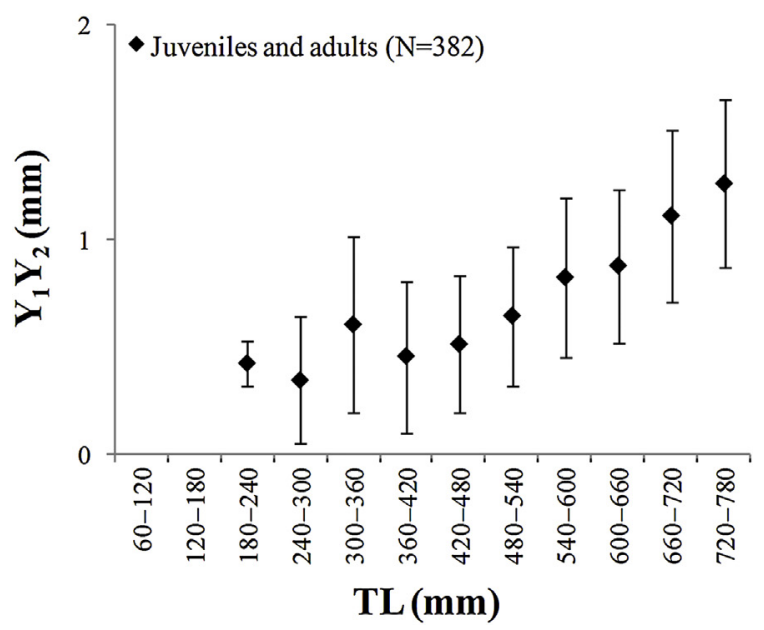

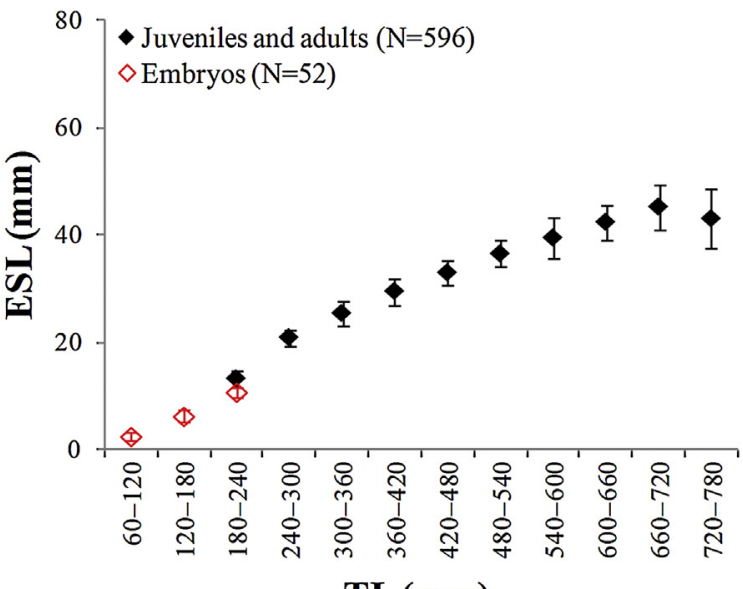

TL $(\mathbf{m m})$

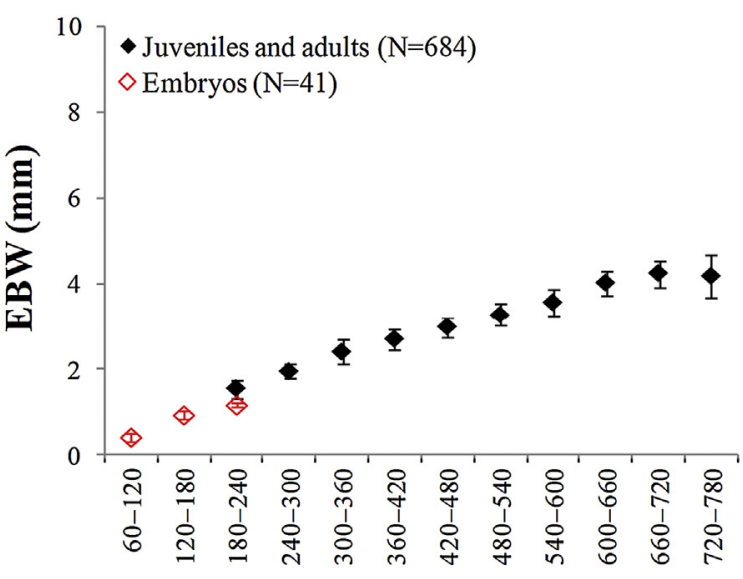

TL $(\mathbf{m m})$

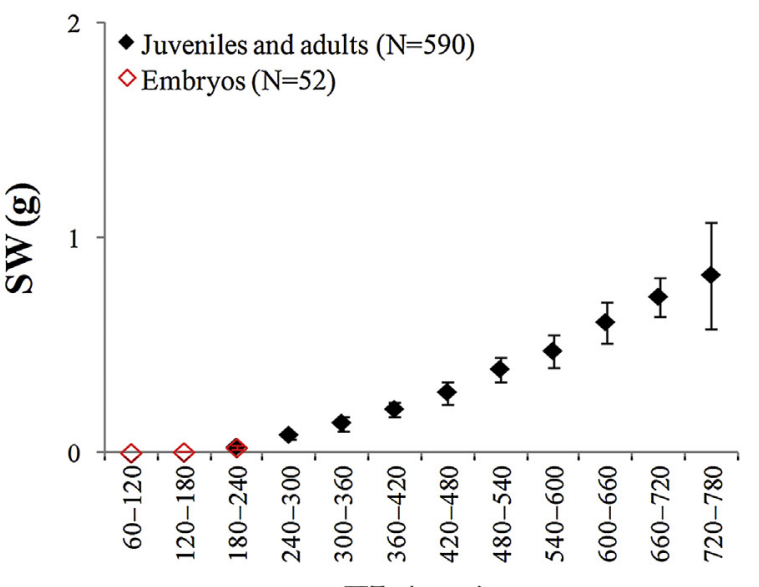

TL $(\mathbf{m m})$

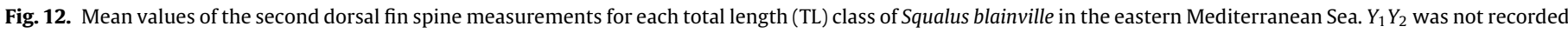

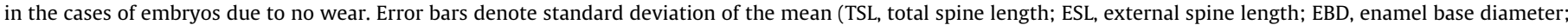
EBW, enamel base width and $Y_{1} Y_{2}$, diameter at no wear point in $\mathrm{mm}$; SW, spine weight in $\mathrm{g}$ ).

example, in Squalus mitsukurii the mean CV value equalled $22.9 \%$ (Paiboonleeskul et al., 2013), while in S. acanthias CV ranged from 10.47 to $12.48 \%$ (Bubley et al., 2012) reaching 19\% (Rice et al., 2009).

\subsection{Aging procedure for S. blainville}

The second dorsal fin spine has been widely used in aging several squalid sharks including S. acanthias (e.g. Bubley et al., 2012),
S. megalops (Watson and Smale, 1999), Etmopterus baxteri (Irvine et al., 2006a), C. crepidater (Irvine et al., 2006b), Etmopterus pusillus (Coelho and Erzini, 2007) and Etmopterus spinax (Coelho and Erzini, 2008). However, our study proved the usefulness of both spines confirming previous findings (e.g. Pajuelo et al., 2011).

In two individuals whose second dorsal fin spine was broken, while the first one was missing, we considered Ketchen's correction curve (1975) to compensate for the lost growth bands. The 
spine diameter (EBD) considered in the relevant equation was measured with special attention, since it was shown that errors in measuring this feature can produce differences from 1 to 19 yrs between different readers examining the same spine (McFarlane and King, 2009). Moreover, estimating the age of 13 individuals from both broken second dorsal fin spine through the correction curve and the unworn first spine, revealed that high precision can be achieved through Ketchen's method (1975). This method was also adopted in S. acanthias (e.g. Soldat, 1982; Nammack et al., 1985; Jones and Ugland, 2001; Demirhan and Seyhan, 2007) and S. megalops (Watson and Smale, 1999; Pajuelo et al., 2011). Actually, better aging results were produced when this method was applied (Soldat, 1982; Nammack et al., 1985; Beamish and McFarlane, 1985), allowing the same time the full use of all the available hard structures (Nammack et al., 1985). On the other hand, Bubley et al. (2012) showed that Ketchen's equation (1975) overestimated the age of $S$. acanthias. Thus, they proposed the use of vertebral centra, instead of spines, as a more reliable and accurate method for aging, especially older individuals whose spine wear must be considered.

\subsection{Growth results and comparison with previous aging studies}

The estimated VBGF parameters of $S$. blainville (Table 8) revealed that males have a higher $k$ value, but a lower $L_{\infty}$ than females, indicating that they reach their theoretical average maximum length faster than females. However, this is probably an artifact since the maximum theoretical length of males was not as large as the observed one. The lower $L_{\infty}$ value in males could be attributed to the lack of samples at the upper extreme of their size range. This view is also supported by the fact that no statistically significant differences were found in the mean TL between females and males in the majority of the age classes (Table 2), indicating a similar growth pattern for both sexes. More samples representing the largest size classes of the species would confirm this hypothesis and could also contribute to a more precise estimation of its longevity.

In the studied area, S. blainville exhibited a slower growth rate in comparison to other localities in the Mediterranean Sea (Cannizaro et al., 1995; Marouani et al., 2012). This could be attributed to the different methodology used each time (Table 8) and to differences in localized environmental conditions, in sampling methods (e.g. number of samples per length class) or in growth rates between different stocks.

Cannizaro et al. (1995) found 8 age classes, but may have probably underestimated the age of $S$. blainville, since the centra of most dogfishes are poorly calcified and do not produce reliable band counts (Wood et al., 1979). On the other hand, Irvine et al. (2006a,b) suggested that the bands in the internal dentin of spines in comparison to the ones in the external enamel surface, may underestimate the age in E. baxteri and C. crepidater, and that they represent a less accurate aging method. In E. baxteri the relationship between internal and external counts suggested that only the first two bands were formed at the same rate. The proportion of internal bands rapidly declined in spines with more than 25 external bands, while after 30 external bands, no more internal bands were deposited (Irvine et al., 2006a). In C. crepidater, both internal and external bands were formed at the same rate only during the first $5 \mathrm{yrs}$. The internal band formation dramatically declined after the formation of 20 external bands and it stopped after 30 yrs (Irvine et al., 2006b). As a consequence, Marouani et al. (2012) by examining the internal band formation in the spines of S. blainville, may have also underestimated its age. In light of the above, we consider that counting the external bands of the spines is a more accurate method for assessing the age of $S$. blainville, although a species-specific validation study needs to be done. Nevertheless, the interpretation of all aging results concerning S. blainville should be made with caution, especially if they are to form the basis of population dynamics models for the management of the species' natural populations (Cailliet et al., 2006). In several species, aging errors have contributed to errors in their population assessment with consequent overexploitation of their populations. This problem usually derives from age underestimation rather than overestimation, resulting in overly optimistic estimates of growth and mortality rate (Campana, 2001 and references therein).

\subsection{Biological traits}

In the present study, sexual dimorphism was revealed based on the length-weight relationships, the length frequency distributions and the length or age at 50\% maturity with females being significantly larger than males and attaining maturity older than them. This pattern actually characterizes the majority of sharks and has been previously reported for the same species (Cannizaro et al., 1995; Sion et al., 2003; Kousteni and Megalofonou, 2011), but also for other sharks (Capapé, 1985; Girard and DuBuit, 1999). The evolution of larger body size in female $S$. blainville has probably arisen from their live-bearing reproductive mode and the resulting effect of female body size on fecundity. A larger female body is necessary to support ovaries with large oocytes, but also well-developed embryos (Sims, 2005).

The condition factor $(K)$ reflects, through its variations, the physiological state of the fish in relation to its welfare (Le Cren, 1951). It is based on the hypothesis that heavier individuals of a given length are in better condition (Bagenal and Tesch, 1978). In the case of $S$. blainville from the eastern Mediterranean Sea, the mean $K$ value was low in females (mean $=0.38 \pm 0.05$ ) and males ( mean $=0.37 \pm 0.04$ ), and in the range of the ones that we estimated based on the published length-weight equations in the Sicilian Channel ( 0.49 and 0.48 for females and males, respectively) (Cannizaro et al., 1995) and in the Gulf of Gabès ( 0.45 and 0.28 for females and males, respectively) (Marouani et al., 2012). Our results showed that the lowest $K$ values were observed during the less gonadal and hepatic development in both sexes. Seasonal fluctuations were also observed in mean $K$ of both sexes, which reflected the seasonal variation in both gonadosomatic (GSI) and hepatosomatic (HSI) indices. It seems that the rhythm of fat accumulation is following the rhythm of the reproductive maturation process, both influencing the $K$ factor.

Considering the fact that statistically significant between-sex differences were found in all somatic indices only in mature individuals with higher mean values in females than males, it is assumed that the level of maturity affects greatly not only the physiological state of females but also the development of their liver that helps them to correspond to the increased energy demands during reproduction (Koob and Callard, 1999). It is well known that the liver plays a key role during the reproduction of female sharks, since it is involved in yolk formation (Koob and Callard, 1999).

It was quite interesting to notice that in both sexes the mean HSI was decreasing during the first 5-6 yrs of life and after that time it started increasing. Negatively buoyant benthic fishes, such as rays, skates and several sharks must exert energy to swim off the bottom and remain afloat (Phleger, 1998). Sharks lack the gas-filled swim-bladder, which functions primarily as a buoyancy organ in teleosts (Phleger, 1991). Instead, they have large livers containing lots of oil in order to regulate the depth at which they can swim (Phleger, 1998). Particularly, the squalidae species have liver containing massive amounts of squalene (Nevenzel, 1989) that acts as a buoyancy controller (Phleger, 1998). Given the above, we assume that liver plays an important role in the first years of life of the demersal $S$. blainville by helping juveniles to remain afloat and regulate better their movements in order to avoid predation and/or to have a better access to food. Additionally, the large liver that the new born embryos have possibly reflects their high need for easy 
Table 8

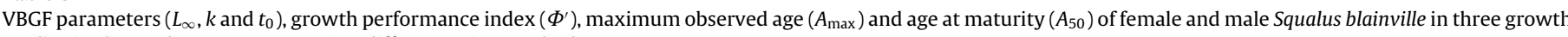
studies in the Mediterranean Sea using different aging methods.

\begin{tabular}{|c|c|c|c|c|c|c|c|c|c|}
\hline Sex & $L_{\infty}(\mathrm{mm})$ & $k\left(\mathrm{yr}^{-1}\right)$ & $t_{\mathrm{o}}(\mathrm{yrs})$ & $\Phi^{\prime}$ index & $A_{\max }(\mathrm{yrs})$ & $A_{50}(\mathrm{yrs})$ & Aging method & Area & Authors \\
\hline $\mathrm{F}$ & 1179 & 0.10 & -1.38 & 5.14 & 8 & 5.1 & Counting bands in & \multirow[b]{2}{*}{ Central Mediterranean } & \multirow{2}{*}{ Cannizaro et al. (1995) } \\
\hline M & 960 & 0.13 & -1.39 & 5.08 & 8 & 3.3 & vertebrae sections & & \\
\hline $\mathrm{F}$ & 1057 & 0.11 & -1.12 & 5.09 & 19 & 7.44 & Counting bands in & \multirow{2}{*}{ Central Mediterranean } & \multirow{2}{*}{ Marouani et al. (2012) } \\
\hline M & 911 & 0.14 & -1.42 & 5.07 & 15 & 4.79 & spine sections & & \\
\hline $\mathrm{F}$ & 1097 & 0.03 & -5.58 & 4.56 & 28 & 17.03 & Counting external & \multirow{2}{*}{ Eastern Mediterranean } & \multirow{2}{*}{ Present study } \\
\hline M & 665 & 0.08 & -3.35 & 4.55 & 22 & 11.31 & bands in spines & & \\
\hline
\end{tabular}

access to energy reserves. During the early stages of life there is probably a greater demand for energy consumption that has to be ensured for their survival. On the other hand, the mean GSI and $K$ were increasing gradually from the new born embryos toward the oldest individuals. However, there was a sudden increase in mean GSI at the age 16-17 yrs for females and 11 yrs for males, which corresponded to the age at first maturity that was 17.03 and 11.31 yrs for females and males, respectively.

\section{Main conclusion}

This study contributes to the general knowledge of a poorly known shark species, the longnose spurdog S. blainville. Overall, the results confirm that $S$. blainville is a long lived (maximum observed age of $28 \mathrm{yrs}$ ), slow growing ( $k=0.03$ and $0.08 \mathrm{yr}^{-1}$ for females and males, respectively) and late maturing species ( $L_{50}=568.1$ and $L_{50}=460.6 \mathrm{~mm}$ for females and males, respectively). Actually, aging 569 individuals revealed that the species attains sexual maturity at a later age than it has been so far known $\left(T_{50}=17.03\right.$ and 11.31 yrs for females and males, respectively). The aging results obtained from the examination of the external banding pattern of the spines were of high precision, if one considers the longevity of S. blainville and the difficulty in the aging procedure itself. At the same time the suitability of the first dorsal fin spine as an aging structure in the species was confirmed. Given that inaccuracies in age estimations may lead to population collapse, there is an urgent need for species-specific age validation in view of the broad range of the species longevity that came up from three different aging methods.

\section{Acknowledgements}

This study is part of a PhD thesis that is conducted at the Faculty of Biology, National and Kapodistrian University of Athens, and has been co-financed by the European Union (European Social FundESF) and Greek national funds through the Operational Program "Education and Lifelong Learning" of the National Strategic Reference Framework (NSRF)-Research Funding Program: Heracleitus II. Investing in a knowledge society through the European Social Fund. We deeply thank Mrs. Chryssi Mytilineou and Dr. Christopher J. Smith for providing a part of samples from the Ionian Sea through the CoralFISH project (European Community's FP7 under grant No 213144; Co-financing was provided to HCMR from the Greek General Secretariat for Research and Technology). We also thank Dr. D. Damalas for the analytical support by running R and Mrs. N. Milatou for aging 70 individuals as a second reader. We are indebted to the reviewers for their suggestions to improve the manuscript.

\section{References}

Bagenal, T.B., Tesch, A.T., 1978. Conditions and Growth Patterns in Fresh Water Habitats. Blackwell Scientific Publications, Oxford.

Beamish, R.J., Fournier, D.A., 1981. A method for comparing the precision of a set of age determinations. Can. J. Fish. Aquat. Sci. 38, 982-983.

Beamish, R.J., McFarlane, G.A., 1983. The forgotten requirement for age validation in fisheries biology. Trans. Am. Fish. Soc. 112 (6), 735-743.
Beamish, R.J., McFarlane, G.A., 1985. Annulus development on the second dorsa spines of the spiny dogfish (Squalus acanthias) and its validity for age determinations. Can. J. Fish. Aquat. Sci. 42, 1799-1805.

Bubley, W.J., Kneebone, J., Sulikowski, J.A., Tsang, P.C.W., 2012. Reassessment of spiny dogfish Squalus acanthias age and growth using vertebrae and dorsal-fin spines. J. Fish. Biol. 80 (5), 1300-1319.

Cailliet, G.M., 1990. Elasmobranch age determination and verification: an updated review. In: Pratt Jr., H.L., Gruber, S.H., Taniuchi, T. (Eds.), Elasmobranchs as Living Resources: Advances in the Biology, Ecology, Systematics, and Status of the Fisheries. NOAA Tech. Rep. NMFS 90. U.S. Department of Commerce, Washington, DC, pp. 157-165.

Cailliet, G.M., Goldman, K.T., 2004. Age determination and validation in chondrichthyan fishes. In: Carrier, J.C., Musick, J.A., Heithaus, M.R. (Eds.), Biology of Sharks and Their Relatives. CRC Press, Boca Raton, FL, pp. 399-448.

Cailliet, G.M., Smith, W., Mollet, H., Goldman, K., 2006. Age and growth studies of chondrichthyan fishes: the need for consistency in terminology, verification, validation, and growth function fitting. Environ. Biol. Fish. 77, 211-228.

Campana, S.E., 2001. Review paper: accuracy, precision and quality control in age determination, including a review of the use and abuse of age validation methods. J. Fish. Biol. 59, 197-242.

Campana, S.E., Annand, M.C., McMillan, J.I., 1995. Graphical and statistical methods for determining the consistency of age determinations. Trans. Am. Fish. Soc. 124, $131-138$

Campana, S.E., Jones, C., McFarlane, G.A., Myklevoll, S., 2006. Bomb dating and age validation using the spines of spiny dogfish (Squalus acanthias). Environ. Biol. Fish. 77, 327-336.

Cannizaro, L., Rizzo, P., Levi, D., Gancitano, S., 1995. Age determination and growth of Squalus blainvillei (Risso 1826). Fish. Res. 23, 113-125.

Capapé, C., 1975. Etude du régime alimentaire de Squalus bainvillei (Risso, 1826) des côtes tunisiennes. Bull. Inst. Océanogr. Pêche, Salammbo. 4, 61-73.

Capapé, C., 1985. Nouvelle description de Centrophorus granulosus (Schneider, 1801) (Pisces, Squalidae). Données sur la biologie de la reproduction et le régime alimentaire des spécimens des côtes tunisiennes. Bull. Inst. Natl. Sci. Technol. Oceanogr. 12, 97-141.

Chang, W.Y.B., 1982. A statistical method for evaluating the reproducibility of age determination. Can. J. Fish. Aquat. Sci. 39, 1208-1210.

Clarke, M.W., Irvine, S.B., 2006. Terminology for the ageing of chondrichthyan fish using dorsal-fin spines. Environ. Biol. Fish. 77, 273-277.

Clarke, M.W., Connolly, P.L., Bracken, J.J., 2002a. Age estimation of the exploited deepwater shark Centrophorus squamosus from the continental slopes of the Rockall Trough and Porcupine Bank. J. Fish Biol. 60, 501-514.

Clarke, M.W., Connolly, P.L., Bracken, J.J., 2002b. Catch, discarding, age estimation, growth and maturity of the squalid shark Deania calceus west and north of Ireland. Fish. Res. 56, 139-153.

Coelho, R., Erzini, K., 2007. Population parameters of the smooth lanternshark, Etmopterus pusillus, in southern Portugal (NE Atlantic). Fish. Res. 86, 42-57.

Coelho, R., Erzini, K., 2008. Life history of a wide-ranging deepwater lantern shark in the north-east Atlantic, Etmopterus spinax (Chondrichthyes: Etmopteridae) with implications for conservation. J. Fish Biol. 73, 1419-1443.

Coelho, R., Erzini, K., 2010. Depth distribution of the velvet belly, Etmopterus spinax, in relation to growth and reproductive cycle: the case study of a deep-water lantern shark with a wide-ranging critical habitat. Mar. Biol. Res. 6, 381-389.

Compagno, L.J.V., 1984. FAO species catalogue. Sharks of the world: an annotated and illustrated catalogue of shark species known to date. Part I. Hexanchiformes to Lamniformes. FAO Fish. Synop. 125, 4.

Conrath, C.L., 2004. Reproductive biology. In: Musick, J.A., Bonfil, R. (Eds.), Elasmobranch Fisheries Management Techniques. Asia-Pacific Economic Cooperation, Singapore, pp. 133-164.

Conrath, C.L., Gelsleichter, J., Musick, J.A., 2002. Age and growth of the smooth dog fish (Mustelus canis) in the northwest Atlantic Ocean. Fish. Bull. 100, 674-682.

Cotton, C.F., Grubbs, R.D., Daly-Engel, T.S., Lynch, P.D., Musick, J.A., 2011. Age, growth and reproduction of a common deep-water shark, shortspine spurdog (Squalus cf. mitsukurii) from Hawaiian waters. Mar. Freshw. Res. 62, 811-822.

Cotton, C.F., Andrews, A.H., Cailliet, G.M., Grubbs, R.D., Irvine, S.B., Musick, J.A. 2014. Assessment of radiometric dating for age validation of deep-water dogfish (Order: Squaliformes) finspines. Fish. Res. 151, 107-113.

Demirhan, S.A., Seyhan, K., 2007. Life history of spiny dogfish, Squalus acanthias (L. 1758), in the southern Black Sea. Fish. Res. 85, 210-216.

Demirhan, S.A., Ogut, H., Engin, S., Başusta, N., Genç, E., 2006. Difficulties in age readings from dorsal spines of spiny dogfish Squalus acanthias L., 1758. In Basusta, N., Keskin, Ç, Serena, F., Seret, B. (Eds.), The Proceedings of the Workshop 
on Mediterranean Cartilaginous Fish with Emphasis on Southern and Eastern Mediterranean. Turkish Mar. Res. Found. Publ., vol. 23, pp. 28-34.

Dulvy, N.K., Fowler, S.L., Musick, K.A., Cavanagh, R.D., Kyne, P.M., Harrison, L.R., et al., 2014. Extinction risk and conservation of the world's sharks and rays. ELife 3, e00590.

Girard, M., DuBuit, M.H., 1999. Reproductive biology of two deep-water sharks from the British Isles, Centroscymnus coelolepis and Centrophorus squamosus (Chondrichthyes: Squalidae). J. Mar. Biol. Assoc. U. K. 79, 923-931.

Holden, M.J., Meadows, P.S., 1962. The structure of the spine of the spur dogfish (Squalus acanthias) and its use for age determination. J. Mar. Biol. Assoc. U. K. 42 179-197.

Irvine, S.B., Stevens, J.D., Laurenson, L.J.B., 2006a. Comparing external and interna dorsal-spine bands to interpret the age and growth of the giant lantern shark, Etmopterus baxteri (Squaliformes: Etmopteridae). Environ. Biol. Fish. 77 (3-4), 253-264

Irvine, S.B., Stevens, J.D., Laurenson, L.J.B., 2006b. Surface bands on deepwater squalid dorsal-fin spines: an alternative method for ageing the golden dogfish Centroselachus crepidater. Can. J. Fish. Aquat. Sci. 63, 617-627.

IUCN, 2014. IUCN Red List of Threatened Species. Version 2014.2, http://www iucnredlist.org (accessed 02.10.14).

Jensen, A.C., 1965. Life history of the spiny dogfish. Fish. Bull. 65, 527-554.

Jones, T.S., Ugland, K.I., 2001. Reproduction of female spiny dogfish, Squalus acanthias, in the Oslofjord. Fish. Bull. 99, 685-690.

Kabasakal, H., 2002. Stomach contents of the longnose spurdog Squalus blainvillei Risso, 1826) from the North-Eastern Aegean Sea. Ann. Ser. Hist. Nat. 12 (2), $161-166$

Kaganovskaia, S.M., 1933. A method of determining the age and composition of the catches of the spiny dogfish (Squalus acanthias L.). Bull. Far East Acad. Sci. U. S. S. R. 1-3, 139-141 (Transl, from Russian by Fish. Mar. Ser. Transl. Ser. No. 128, 1960)

Ketchen, K.S., 1975. Age and growth of dogfish (Squalus acanthias) in British Columbia waters. J. Fish. Res. Board Can. 32, 13-59.

Kimura, D.K., 1980. Likelihood methods for the von Bertalanffy growth curve. Fish. Bull. 77 (4), 765-776.

King, M., 1995. Fisheries Biology, Assessment and Management. Fishing New Books Oxford.

Koob, T.J., Callard, I.P., 1999. Reproductive endocrinology of female elasmobranchs lessons from the little skate (Raja erinacea) and spiny dogfish (Squalus acanthias). J. Exp. Zool. 284, 557-574.

Kousteni, V., Megalofonou, P., 2011. Reproductive biology and embryonic development of Squalus blainvillei in the eastern Mediterranean Sea. Sci. Mar. 75 (2) 237-249.

Kyne, P.M., Simpfendorfer, C.A., 2007. A collation and summarization of available data on deepwater chondrichthyans: biodiversity, life history and fisheries. In: A Report Prepared by the IUCN SSC Shark Specialist Group for the Marine Conservation Biology Institute, Cambridge.

Le Cren, E.D., 1951. The length-weight relationship and seasonal cycle in gonada weight and condition in the perch, Perca fluviatilus. J. Anim. Ecol. 20, 201-219.

Maisey, J.G., 1979. Fin spine morphogenesis in squalid and heterodontid sharks. Zool. J. Linn. Soc. 66, 161-183.

Marouani, S., Kadri, H., Saidi, B., Morize, E., Bouain, A., Bradai, M.N., 2012. Age growth, longevity, natural mortality and maturity of the longnose spurdog, Squalus blainvillei (Chondrichthyes: Squalidae), in the Gulf of Gabès (Central Mediterranean Sea). Cah. Biol. Mar. 53 (2), 197-204.

Martinho, F., Sá, C., Fãlcao, J., Cabral, H.N., Pardal, M.Â., 2012. Comparative feeding ecology of two elasmobranch species, Squalus blainville and Scyliorhinus canicula, off the coast of Portugal. Fish. Bull. 110, 71-84.

McFarlane, G.A., Beamish, R.J., 1987. Validation of the dorsal spine method of age determination for spiny dogfish. In: Summerfelt, R.C., Hall, G.E. (Eds.), Age and Growth of Fish. Iowa State University Press, Ames, IA, pp. 287-300.

McFarlane, G.A., King, J.R., 2009. Re-evaluating the age determination of spiny dogfish using oxytetracycline and fish at liberty up to 20 years. In: Gallucci, V.F. McFarlane, G.A., Bargmann, G.G. (Eds.), Biology and Management of Dogfish Sharks. American Fisheries Society, Bethesda, MD, pp. 153-160.

Munro, J.L., Pauly, D., 1983. A simple method for comparing growth of fishes and invertebrates. ICLARM Fishbyte 1, 5-6.

Musick, J.A., 1999. Ecology and conservation of long-lived marine animals. In: Musick, J.A. (Ed.), Life in the Slow Lane: Ecology and Conservation of Long-Lived Marine Animals. American Fisheries Society, Bethesda, MD, pp. 1-10.
Nammack, M.F., Musick, J.A., Colvocoresses, J.A., 1985. Life history of spiny dogfish off the northeastern United States. Trans. Am. Fish. Soc. 114, 367-376.

Nevenzel, J.C., 1989. Biogenic hydrocarbons of marine organisms. In: Ackman, R.G. (Ed.), Marine Biogenic Lipids, Fats, and Oils. CRC Press, Florida, pp. 3-71.

Ondrias, L.C., 1971. A list of the fresh and sea water fishes of Greece. Hell. Oceanol. Limnol. 7, 13-14.

Orlov, A.M., Kulish, E.F., Mukhametov, I.N., Shubin, O.A., 2011. Age and growth of spiny dogfish Squalus acanthias (Squalidae, Chondrichthyes) in pacific waters off the Kuril Islands. J. Ichthyol. 51 (1), 42-55.

Paiboonleeskul, K., Romratanapun, S., Thapanand-Chaidee, T., 2013. Ageing of shortspine spurdog in the Andaman Sea of Thailand. Maejo Int. J. Sci. Technol. 7 , $14-21$.

Pajuelo, J.G., García, S., Lorenzoa, J.M., Gonzáleza, J.A., 2011. Population biology of the shark, Squalus megalops, harvested in the central-east Atlantic Ocean. Fish. Res. 108, 31-41.

Pauly, D., Munro, J.L., 1984. Once more on the comparison of growth fish and invertebrates. ICLARM Fishbyte 2, 21

Phleger, C.F., 1991. Biochemical aspects of buoyancy in fishes. In: Hochachka, P.W. Mommsen, T.P. (Eds.), Biochemistry and Molecular Biology of Fishes. Elsevier Science Publishers B.V., Amsterdam, pp. 209-247.

Phleger, C.F., 1998. Buoyancy in marine fishes: direct and indirect role of lipids. Am. Zool. 38, 321-330.

Pratt, H.L., Carrier, J.C., 2005. Elasmobranch courtship and mating behavior. In: Hamlett, W.C. (Ed.), Reproductive Biology and Phylogeny of Chondrichthyes. Science Publishers Inc., Enfield, NH, pp. 129-170.

R Development Core Team, 2009. R: A Language and Environment for Statistical Computing. R Foundation for Statistical Computing, Vienna, Austria.

Rice, J.S., Gallucci, V.F., Kruse, G.H., 2009. Evaluation of the precision of age estimates for spiny dogfish. In: Gallucci, V.F., McFarlane, G.A., Bargmann, G.G. (Eds.), Biology and Management of Dogfish Sharks. American Fisheries Society, Bethesda MD, pp. 161-168.

Ricker, W.E., 1975. Computation and interpretation of biological statistics of fish populations. Bull. Fish. Res. Board Can. 191, 1-382.

Rochet, M.J., Trenkel, V.M., 2003. Which community indicators can measure the impact of fishing? A review and proposals. Can. J. Fish. Aquat. Sci. 60, 86-99.

Saunders, M.W., McFarlane, G.A., 1993. Age and length-at-maturity of the female spiny dogfish, Squalus acanthias, in the strait of Georgia, British Columbia Canada. Environ. Biol. Fish. 38, 49-57.

Simpfendorfer, C.A., 1993. Age and growth of the Australian sharpnose shark, Rhizoprionodon taylori, from North Queensland, Australia. Environ. Biol. Fish. 36 233-241.

Sims, D.W., 2005. Differences in habitat selection and reproductive strategies of male and female sharks. In: Ruckstuhl, K.E., Neuhaus, P. (Eds.), Sexual Segregation in Vertebrates: Ecology of the Two Sexes. Cambridge University Press, UK, pp. $127-147$.

Sion, L., D'Onghia, G., Matarrese, A., Mytilineou, C., 2003. First data on distribution and biology of Squalus blainvillei (Risso, 1826) from the eastern Mediterranean Sea. J. Northwest Atl. Fish. Sci. 31, 210-219.

Soldat, V.T., 1982. Age and size of spiny dogfish, Squalus acanthias, in the northwest Atlantic. NAFO Sci. Counc. Stud. 3, 47-52.

Spare, P., Venema, S.C., 1992. Introduction to tropical fish stock assessment. Part I. Manual. FAO Fisheries Technical Paper, 306. FAO, Rome.

Stevens, J.D., Bonfil, R., Dulvy, N.K., Walker, P.A., 2000. The effects of fishing on sharks, rays, and chimaeras (chondrichthyans), and the implications for marine ecosystems. ICES J. Mar. Sci. 57, 476-494

Tribuzio, C.A., Rouse, G.H., Fujioka, J.T., 2010. Age and growth of spiny dogfish (Squalus acanthias) in the Gulf of Alaska: analysis of alternative growth models. Fish. Bull. 108, 119-135.

Tucker, R., 1985. Age validation studies on the spines of the spurdog (Squalus acanthias) using tetracycline. J. Mar. Biol. Assoc. U. K. 65 (3), 641-651.

Von Bertalanffy, L., 1938. A quantitative theory of organic growth (inquiries on growth laws II). Hum. Biol. 10, 181-213.

Watson, G., Smale, M.J., 1999. Age and growth of the shortnose spiny dogfish, Squalus megalops, from the Agulhas Bank, South Africa. S. Afr. J. Mar. Sci. 21, 9-18.

Wood, C.C., Ketchen, K.S., Beamish, R.J., 1979. Population dynamics of spiny dogfish (Squalus acanthias) in British Columbia waters. J. Fish. Res. Board Can. 36 (6), 647-656.

Zar, J.H., 1999. Biostatistical Analysis, fourth ed. Prentice Hall, New Jersey. 